\title{
20. PETROLOGY OF IGNEOUS ROCKS FROM THE CELEBES SEA BASEMENT1
}

\author{
G. Serri, ${ }^{2}$ P. Spadea,${ }^{3}$ L. Beccaluva,${ }^{4}$ L. Civetta,${ }^{5}$ M. Coltorti, ${ }^{4}$ \\ J. Dostal, ${ }^{6}$ F. Sajona, ${ }^{7}$ C. Vaccaro, ${ }^{4}$ and O. Zeda ${ }^{8}$
}

\begin{abstract}
Major and trace elements, mineral chemistry, and $\mathrm{Sr}-\mathrm{Nd}$ isotope ratios are reported for representative igneous rocks of Ocean Drilling Program Sites 767 and 770. The basaltic basement underlying middle Eocene 6radiolarianbearing red clays was reached at $786.7 \mathrm{mbsf}$ and about $421 \mathrm{mbsf}$ at Sites 767 and 770 , respectively. At Site 770 the basement was drilled for about $106 \mathrm{~m}$. Eight basaltic units were identified on the basis of mineralogical, petrographical, and geochemical data. They mainly consist of pillow lavas and pillow breccias (Units A, B, D, and $\mathrm{H}$ ), intercalated with massive amygdaloidal lavas (Units $\mathrm{C} 1$ and $\mathrm{C} 2$ ) or relatively thin massive flows (Unit E). Two dolerite sills were also recognized (Units $\mathrm{F}$ and $\mathrm{G}$ ).

All the rocks studied show the effect of low-temperature seafloor alteration, causing almost total replacement of olivine and glass. Calcite, clays, and Fe-hydroxides are the most abundant secondary phases. Chemical mobilization due to the alteration processes has been evaluated by comparing elements that are widely considered mobile during halmyrolysis (such as low-field strength elements) with those insensitive to seafloor alteration (such as $\mathrm{Nb}$ ). In general, $\mathrm{MgO}$ is removed and $\mathrm{P}_{2} \mathrm{O}_{5}$ occasionally enriched during the alteration of pillow lavas. $\mathrm{Tl}, \mathrm{Cs}, \mathrm{Li}, \mathrm{Rb}$, and $\mathrm{K}$, which are the most sensitive indicators of rock/seawater interaction, are generally enriched. The most crystalline samples appear the least affected by chemical changes.

Plagioclase and olivine are continuously present as phenocrysts, and clinopyroxene is confined in the groundmass. Textural and mineralogical features as well as crystallization sequences of Site 770 rocks are, in all, analogous to typical mid-ocean-ridge basalts (MORBs). Relatively high content of compatible trace elements, such as $\mathrm{Ni}$ and $\mathrm{Cr}$, indicate that these rocks represent nearly primitive or weakly fractionated MORBs.

All the studied rocks are geochemically within the spectrum of normal MORB compositional variation. Their $\mathrm{Sr} / \mathrm{Nd}$ isotopic ratios plot on the mantle array $\left({ }^{87} \mathrm{Sr} /{ }^{87} \mathrm{Sr} 0.70324-0.70348\right.$ with $\left.{ }^{143} \mathrm{Nd} /{ }^{144} \mathrm{Nd} 0.51298-0.51291\right)$ outside the field of Atlantic and Pacific MORBs. However, Sr and Nd isotopes are typical of both Indian Ocean MORBs and of some back-arc basalts, such as those of Lau Basin. The mantle source of Celebes basement basalts does not show a detectable influence of a subduction-related component.

The geochemical and isotopic data so far obtained on the Celebes basement rocks do not allow a clear discrimination between mid-ocean ridge and back-arc settings.
\end{abstract}

\section{INTRODUCTION}

One of the major objectives of Leg 124 was to study the nature of the basement of the Sulu and Celebes seas, two small basins located in a structurally complex region where the Eurasian, Philippine Sea, and Australian plates converge. This goal was successfully reached in both basins (Fig. 1).

In particular, the basement of the Celebes Sea was drilled in two sites, 767 and 770 , for lengths of $0.4 \mathrm{~m}$ and $106 \mathrm{~m}$, respectively. Radiolarian-bearing red clays found directly above the basement gave a middle Eocene age (about $43 \mathrm{Ma}$ ) for both sites. The basement consists of a sequence of basaltic pillow- and pillow-breccia lavas and sheet flows injected by dolerite sills. Preliminary on-board analyses revealed a

${ }^{1}$ Silver, E. A., Rangin, C., et al., von Breymann, M. T., et al., 1991. Proc. ODP, Sci. Results, 124: College Station, TX (Ocean Drilling Program).

${ }^{2}$ Dipartimento di Scienze della Terra, Università di Pisa, Via S. Maria, 53, 1-56100 Pisa, Italy.

${ }^{3}$ Istituto di Scienze della Terra, Università di Udine, Via Cotonificio, 114, 1- 33100 Udine, Italy.

${ }^{4}$ Istituto di Mineralogia, Università di Ferrara, Corso Ercole I D'Este, 32 , 1- 44100 Ferrara, Italy.

${ }^{5}$ Dipartimento di Geofisica e Vulcanologia, Università di Napoli, Largo S. Marcellino 10, 1-80138 Napoli, Italy.

${ }^{6}$ Department of Geology, St. Mary's University, Halifax, Nova Scotia B3H 3C3, Canada.

${ }_{7}$ Petrolab. Mines and Geosciences Bureau, North Avenue, Quezon City, Philippines.

Istituto di Mineralogia, Università di Parma, Viale delle Scienze, 78, 1-43100 Parma, Italy. tholelitic composition, showing a petrogenetic affinity with mid-ocean ridge basalts (MORB).

Despite the number and quality of data obtained during Leg 124 , the origin of the Celebes Sea is still under discussion. The sedimentary record indicates that the basin developed far from continental or major volcanic arc sources, but does not distinguish between the following hypotheses: (1) trapped fragment of the Indian Ocean or the Philippine Sea oceanic crusts (Lee and McCabe, 1986; Silver, et al. 1989); (2) fragmentation and rifting of the Eurasian continental margin with a mechanism analogous to the formation of the South China Sea (Rangin, 1989); (3) inter-arc, subduction-related marginal basin similar to the Parece-Vela Basin.

The nature of the basaltic crust often makes it possible to recognize the different geodynamic settings in which marginal basins may originate. Though generally similar to tholeiites erupted at mid-ocean ridges, the basalts from subductionrelated marginal basins may show some distinctive mineralogical, textural, and geochemical features due to the influence of subducted lithosphere on magma generation processes. This is widely considered as related to the variable addition to the mantle wedge of volatile and large-ion lithophile elements (LILE) derived from a subducted lithospheric slab (Saunders et al., 1984). The geochemical signature produced in this process may be detected in the basalts erupted in intra-arc and back-arc settings, particularly at an early stage of marginal basin opening. Recently it has been shown that some back-arc basin basalts, such as those from Lau (Volpe et al., 1988) and north Fiji (Price et al., 1990) basins, range from normal to 




Figure 1. Location of the sites drilled during ODP Leg 124. Bathymetric contours are in meters. Oceanic basement is hatched.

enriched MORBs, and even ocean island basalt-like components are occasionally present.

Mineral chemistry and texture give further indications about crystal-liquid equilibria during fractionation processes in different settings: these provide alternative criteria to infer magmatic processes in altered rocks in which the content of volatile and most large-ion lithophile (LIL) elements was changed by secondary mobilization processes.

This work reports petrological, mineralogical, geochemical, and isotopic data obtained in various shore-based laboratories with the aim of defining the nature of the Celebes Sea basement, and putting constraints derived from the chemical geodynamics on the tectonic setting of its origin.

\section{ANALYTICAL METHOD}

Minerals (Tables 2, 3, and 4) were analyzed at the University of Milan using an electron-probe microanalyzer with SEMQ-ARL unit at an accelerating voltage of $15 \mathrm{kV}$, speci- men current of $5 \mathrm{nA}$, beam diameter of 2 to $3 \mu \mathrm{m}$ and counting time of $20 \mathrm{~s}$. The Bence and Albee factors (1968) were used for data reduction.

X-ray fluorescence (XRF) analyses (Tables 5 and 6) were made on board using ODP techniques on whole-rock samples (Rangin, Silver, von Breymann, et al., 1990). At the University of Udine, XRF analyses were made for major elements, $\mathrm{Cr}$, and $\mathrm{Sc}$ on lithium borate glass disks (flux to sample ratio 10:1 to overcome matrix effects) and for trace elements (V, $\mathrm{Ni}, \mathrm{Rb}, \mathrm{Sr}, \mathrm{Y}, \mathrm{Zr}$, and $\mathrm{Nb}$ ) on powder pellets (Compton scattering technique adopted for matrix absorption corrections), using a Philips wavelength-dispersive automated spectrometer. Rare-earth elements (REE) and Y were determined in the Centre de Recherches Pétrographiques et Géochimiques (C.R.P.G.) of Nancy, France, by inductively coupled plasma (ICP) emission spectrometry (columns A of Table 6). Sc, V, Li, Be, Cs, Rb, Ba, Sr, Zr, Hf, Th, U, Tl, Pb, $\mathrm{Nb}, \mathrm{Y}$, and REE were analyzed at St. Johns Memorial Uni- 
versity by ICP-mass spectrometry (ICP-MS), using the standard addition method to correct for matrix effects (columns B of Table 6). The analytical procedure is described in detail in Jenner et al. (1990). Cross checking of trace-element analyses done on the same sample at Udine, St. Johns, Nancy, and on board allows the following conclusions to be drawn:

1. Major-element analyses are in good agreement except for $\mathrm{SiO}_{2}$ and $\mathrm{Na}_{2} \mathrm{O}$, which are systematically higher by $0.6 \%$ $1.6 \%$ and $0.4 \%-0.6 \%$, respectively (absolute values) in Udine with respect to on-board determination.

2. Excellent agreement between the different laboratories has been found for elements such as $\mathrm{Rb}, \mathrm{Sr}$, and $\mathrm{Nb}$. Note that, for these elements, St.Johns and shipboard determinations are virtually identical. $\mathrm{Zr}$ and $\mathrm{Y}$ determinations by XRF are systematically higher than ICP-MS analyses by about $10 \%$ and $15 \%$, respectively. Y determination by ICP (Nancy) is systematically higher by about $20 \%$ with respect to ICP-MS determination (except Section 124-770C-10R-2, with ICP $40 \%$ higher).

3. There is sufficient agreement between REE analyses by ICP and ICP-MS; within a span of $10 \%-15 \%$ between data.

4. In general, agreement between XRF determination (particularly that obtained on board) and ICP-MS data for V is good, except one Sample (124-770B-20R-3, 10-15 cm).

5. For Sample 124-770C-7R-6, 44-47 cm, the powder analyzed on the ship and in Udine are different. The Udine analysis is reported because ICP and ICP-MS determination was done on the same powder.

6. For Sample 124-770C-12R-2, 38-41 cm, which is a medium-grained olivine dolerite, ICP-MS analyses might not be representative of the bulk rock composition due to the exceedingly small amount of sample $(100 \mathrm{mg})$ analyzed for such a non-homogeneous lithotype. The wide discrepancy between XRF and ICP-MS analyses for $\mathrm{Sr}, \mathrm{Zr}, \mathrm{Y}, \mathrm{Rb}$, and V can be cited to support this argument.

$\mathrm{Sr}$ and $\mathrm{Nd}$ isotopic compositions were obtained at the University of Naples after cold leaching with $2.5 \mathrm{~N}$ (A of Table 6) or $6.5 \mathrm{~N}$ (the latter only for $\mathrm{Sr}, \mathrm{B}$ of Table 6) hydrochloric acid for about $30 \mathrm{~s}$. Measurements were done with a VG 354 mass spectrometer. For the reference sample NBS987, the ${ }^{87} \mathrm{Sr} /{ }^{86} \mathrm{Sr}$ ratio $=0.71026 \pm 2$ and for La Jolla STD the ${ }^{143} \mathrm{Nd} /{ }^{144} \mathrm{Nd}$ ratio $=0.51186 \pm 3$ were obtained. The reported errors are at the $95 \%$ confidence level.

\section{GEOLOGICAL OUTLINE}

The Celebes Sea is $270,000 \mathrm{~km}^{2}$ in extent and has an abyssal plain of 5 to $5.5 \mathrm{~km}$ deep. It is bounded to the north by the Sulu Archipelago, which belongs to the Sulu volcanic arc extending from Borneo to the Zamboanga Peninsula of Mindanao. Deep bathymetric depressions mark the trenches of the active North Sulawesi subduction zone in the south and the Cotobato subduction zone in the west.

At Site 767 , located in the central Celebes Sea at $4^{\circ} 47.5^{\prime} \mathrm{N}$, $123^{\circ} 30.2^{\prime} \mathrm{E}$ at a water depth of $4905 \mathrm{~m}$, the basement was reached at 786.7 meters below seafloor (mbsf). middle Eocene red clays rest directly over the lavas. A total of $42 \mathrm{~cm}$ of basaltic rocks were recovered in the core catcher.

Three holes were drilled at Site 770 , which is located on a bathymetric high at a water depth of $4505 \mathrm{~m}$ about $43 \mathrm{~km}$ north-northeast of Site 767 . Hole $770 \mathrm{~B}$ was drilled to 474 mbsf, including $50 \mathrm{~m}$ of basement. Hole $770 \mathrm{C}$ washed to basement, then cored to $529 \mathrm{mbsf}$, or $106 \mathrm{~m}$ of basement.

The basal sediments at Sites 770 and 767 are middle Eocene radiolaria- bearing red clays with a biostratigraphic age of 42 Ma (Silver et al., 1989) or 45 Ma (Rangin, 1989).
Site 770 has about half the thickness of the sedimentary cover of Site 767 , yet the basal ages are identical. This difference reflects the higher elevation of Site 770 , protecting it from turbidite influence and allowing it to be just above the calcite compensation depth (CCD) in the lowest part. Basement was recovered from 421 to 529 mbsf. Holes $770 \mathrm{~B}$ and $770 \mathrm{C}$ were drilled so close together as to make a separate description of basement lithology unnecessary. The contact between sediment and basement was found at $421 \mathrm{~m}$ in Hole $770 \mathrm{~B}$, and about $2 \mathrm{~m}$ deeper in Hole $770 \mathrm{C}$.

\section{LITHOLOGY}

Combining shipboard results from Holes $770 \mathrm{~B}$ and $770 \mathrm{C}$ with shore-based mineralogical, petrographical, and geochemical analyses, eight basaltic units have been identified (Fig. 2). To avoid confusion with shipboard units, the newly defined units were named from top to bottom with capital letters in alphabetic order and divided as follows:

-Units A, B, and $\mathrm{H}$ are pillow basalt sequences, with the lower part of Unit B consisting of pillow breccia;

-Unit $\mathrm{C}(\mathrm{C} 1$ and $\mathrm{C} 2)$ consists of brecciated, massive amygdaloidal lavas cemented with calcite veins;

-Unit D consists of pillow lavas and pillow breccias;

- Unit $\mathrm{E}$ is made of relatively thin massive lava flows;

-Units $\mathrm{F}$ and $\mathrm{G}$ are identified as dolerite sills.

Shipboard observations indicate that small dikes and dikelets, maximum $30 \mathrm{~cm}$, penetrate Units D, E, and $\mathrm{H}$.

\section{Unit A (Shipboard Unit 1)}

\section{Sparsely Plagioclase Olivine Phyric Basalt Pillow Lavas}

This unit has a thickness of about $18 \mathrm{~m}$, of which approximately $7 \mathrm{~m}$ (Hole 770B) and $6 \mathrm{~m}$ (Hole 770C) were recovered. It consists of sparsely plagioclase $(2 \%-4 \%)$ and olivine $(2 \%-$ $3 \%$ ) phyric pillow basalts, whose quench textures indicate a crystallization at a very high cooling rate (cf. Lofgren, 1979). Fan and bow-tie morphologies of the groundmass plagioclases were found only in samples from the upper part of the sequence. The texture of the studied samples recovered from the lower part of Unit A (Table 1) indicates a lower degree of supercooling, also reflected by the lower amount of mesostasis $(10 \%-30 \%$ vs. $40 \%-70 \%)$. This is in accordance with the shipboard observation, which identifies within Unit A upper and lower parts made up respectively of pillow lavas of small and large $(0.4 \mathrm{~m}-1 \mathrm{~m}$ in diameter $)$ dimensions.

Some samples appear to be nonvesicular; others contain few vesicles (up to $2 \%$ ) often filled with clays and carbonates.

\section{Units B and C: a Modified Interpretation of the Lithology}

There is not a straightforward correlation between the rocks found in Holes $770 \mathrm{~B}$ and $770 \mathrm{C}$.

Shipboard unit 3 of Hole 770B, which has been interpreted as a brecciated pillow lava sequence about $4 \mathrm{~m}$ thick (454.8-458.6 mbsf), has no equivalent at about the same depth in Hole 770C. Here, between 452.2 and $460.8 \mathrm{mbsf}$, there is a basaltic breccia essentially made up of angular clasts and separated by a network of calcite veins. This is lithologically comparable to Unit 4 of Hole 770B (458.6$464.5 \mathrm{mbsf}$ ), which is considered to be a brecciated and veined massive lava flow.

The re-evaluation of shipboard data coupled with new petrochemical analyses allows us to divide Unit 3 of Hole 770B into an upper section (454.8-457.0 mbsf), which consists of highly plagioclase -olivine phyric pillow breccia, and a lower section (457.0-458.6 mbsf) that is made of a breccia 




FORAMIINIFER-NANNOFOSSIL MARL

Unit IIC

DARK GREY CLAYSTONE

Unit IIC

PILLOWLAYAS

Unit A: s pars ely PI-OI phyric basalt pill ow lavas

PILLOW LAYAS AND PILLOW BRECCIAS

Unit B: highly PI-OI phyric basalts, pill owe d and

breccialed

MASSIYE LAYAS

Unit C1 and C2: moderat ely to highly PI-Ol phyric amygdal oidal basalt lava flows, breccialed and veined

PILLOW LAYAS AND PILLOW BRECCIAS

Unit D: mod erat ely to highly PI-OI phyric basaltic pill ow lavas and pillow breccias

MASSIYE LAYAS MTHDIKES

Unit E: moderat ely PI-OI phyric basalt massive

lavas s pars ely intru de d by basaltic dikes

DOLERITE SILL

Unit F: spars ely PI phyric to aphyric dolerite sill

OLIVINEDOLERITE SILL

Unit G: spars ely to mo derat ely OI-PI phyric dolerite sill

\section{PILLOWLAYAS WTHDIKES}

Unit H: moderal ely PI-OI phyric basaltic pillow lavas cut by basaltic dikes

Figure 2. Merged stratigraphic log of Site 770 Holes B and C - Celebes Sea basement.

with angular clasts of a massive lava cemented by veins dominantly of calcite and clays.

\section{Conclusions}

-Unit B (pillow lavas and pillow breccias) of the modified lithostratigraphic sequence of Site 770 basement comprises Unit 2 of Holes $770 \mathrm{~B}$ and $770 \mathrm{C}$ as well as the upper part of Unit 3 of Hole $770 \mathrm{~B}$;

-Unit $\mathrm{C} 1$ includes Unit 3 of Hole $770 \mathrm{C}$, Unit 4 of Hole $770 \mathrm{~B}$, and the lower section (457.0-458.6 mbsf) of Unit 3 of Hole 770B;

-Unit $\mathrm{C} 2$ comprises Units 5 and 6 of Hole B and Unit 4 of Hole $770 \mathrm{C}$.

\section{Unit B}

Highly Plagioclase and Olivine Phyric Basaltic Pillow Lavas and Pillow Breccias

This unit shows a thickness in Hole 770B nearly twice as great as that presented in Hole $770 \mathrm{C}(17.7 \mathrm{~m}$ vs. $9.5 \mathrm{~m})$ of which $7 \mathrm{~m}$ (Hole 770B) and $4 \mathrm{~m}$ (Hole 770C) were recovered.

The rocks are pillow basalts that become brecciated at the base of the newly defined unit. These pillow lavas are easily distinguished from those of Unit A by their high content of phenocrysts of plagioclase (10\%-20\%) and olivine (4\%-10\%). Groundmass textures and amount of mesostasis are compara- 
ble to the upper Unit A that petrographically represents the most quenched facies of Site 770 (Table 1).

Vesicles/amygdales of Unit B are, on average, slightly more abundant (up to $4 \%$ ) and of bigger size (up to $5 \mathrm{~mm}$ ) than in Unit A.

\section{Unit C $(\mathbf{C 1}+\mathbf{C 2})$}

Moderately to Highly Plagioclase and Olivine Phyric Amygdaloidal Basalt Massive Lavas, Brecciated and Veined

The thickness of this unit is comparable in the two holes (770B, about $17 \mathrm{~m}$ of which $7.5 \mathrm{~m}$ recovered; $770 \mathrm{C}$, about 20 $\mathrm{m}$, of which $14 \mathrm{~m}$ recovered).

Lithologically, it consists of amygdaloidal massive lava flows showing strong evidence of in-situ brecciation and cementation through a network of veins, predominantly calcite, and subordinate clays, silica, and Fe-hydroxides. Chilled margins are absent throughout the sequence, but textural variation (Table 1) suggests the existence of at least three cooling units.

The studied samples are moderately plagioclase (3\%-10\%) and olivine $(1 \%-10 \%)$ phyric basalts with intersertal, intergranular, interfasciculate and subophitic groundmass: textures that are normally found in such types of massive lava flows. The lowermost studied sample of Unit C2 is a highly plagioclase $(15 \%)$ phyric basalt, characterized by rare plagioclase megacrysts greater than $1 \mathrm{~cm}$ in size.

The distribution of the amygdales varies throughout the sequence from $2 \%$ to $15 \%$. Altered mesostasis is always present. In contrast with the pillow lava sequences of Units A and $\mathrm{B}$, the mesostasis is volumetrically subordinate and invariably occurs as intersertal patches.

\section{Unit D (Shipboard Unit 5 of Hole 770C)}

\section{Moderately to Highly Plagioclase and Olivine Phyric Basaltic Pillow Lavas and Pillow Breccias}

This unit has a thickness of $18.7 \mathrm{~m}$. (472.1-490.8 mbsf) of which about $5.5 \mathrm{~m}$ were recovered.

Lithologically, it consists of pillow lavas, commonly 10-20 $\mathrm{cm}$ in diameter, with pillow breccia horizons. The studied samples are characterized by variable abundance of plagioclase $(8 \%-15 \%)$ and olivine $(4 \%)$ phenocrysts set in a groundmass with quench textures dominated by spherulitic crystals of plagioclase.

The vesicles $(1 \%-4 \%)$, typically filled with green and brown clays and carbonate, are heterogeneously distributed through the sequence.

Shipboard observation suggests that Sample 124-770B$7 \mathrm{R}-6,43-44 \mathrm{~cm}$ can be interpreted as a cryptocrystalline dikelet about $5 \mathrm{~cm}$ thick intruded in the brecciated part of the unit.

\section{Unit E (Shipboard Unit 6 of Hole 770C)}

\section{Moderately Plagioclase and Olivine Phyric Basalt Massive Lavas cut by Dikes}

This unit is $10.5 \mathrm{~m}$ thick (490.8-501.3 mbsf); about $3 \mathrm{~m}$ were recovered by drilling.

The lithology is not well constrained. Shipboard observation suggests that this sequence consists of three separate cooling units cut by flat-lying minor intrusions. The studied sample was interpreted as a small dike. This is in accordance with the phaneritic medium grain size, subophitic texture, and virtual absence of vesicles/amygdales and mesostasis (Table 1).

\section{Unit F (Shipboard Unit 7)}

\section{Sparsely Plagioclase Phyric to Aphyric Dolerite Sill}

This is a relatively homogeneous massive unit $11.2 \mathrm{~m}$. thick (501.3-512.5 mbsf) of which $5.5 \mathrm{~m}$ were recovered.

The topmost $25 \mathrm{~cm}$ of the unit is characterized by about $10 \%$ of spherical vesicles/amygdales that become scattered or virtually absent going downward. The unit is classified as a dolerite sill with uniform phaneritic appearance. The rocks are subaphyric with uneven distribution of plagioclase phenocrysts up to $2 \%$. The texture is subophitic, with a significant amount (about 15\%) of interstitial mesostasis (Table 1).

\section{Unit G (Shipboard Unit 8)}

\section{Sparsely to Moderately Olivine and Plagioclase Phyric Dolerite Sill}

This unit has a thickness of $10.6 \mathrm{~m}(512.5-523.1 \mathrm{mbsf})$ of which $3.5 \mathrm{~m}$ were recovered.

Lithologically, it is a massive dolerite sill characterized by a variation of both grain size and abundance of phenocrysts with depth. The lower part is coarser-grained and more porphyritic than the upper part. The two studied samples were taken near the base of the sill. Despite their proximity $(15 \mathrm{~cm}$ apart), they show a significant variation in grain size from coarse-medium- grained (Sample 124-770C-12R-2, 31-33 cm) to fine-medium-grained (Sample 124-770C-12R-2, 38-41 cm) rocks. In the latter, the abundance of olivine phenocrysts (Table 1) shows a heterogeneous distribution even at the scale of thin section. Vesicles are virtually absent.

\section{Unit H (Shipboard Unit 9)}

\section{Moderately Plagioclase and Olivine Phyric Basalt Pillow Lavas with Dikes}

This is the lowermost unit of Site 770. Its thickness is $6.4 \mathrm{~m}$ (523.1-529.5 mbsf). Shipboard observation suggests that most of the recovered rocks (about $1.5 \mathrm{~m}$ ) represent pillow lavas. Groundmass texture, amount of mesostasis (about 20\%) and presence of abundant vesicles/amygdales (about 6\%) in the single studied sample (Table 1) do not contradict this interpretation.

\section{PETROGRAPHY}

\section{Primary Feature}

The wide textural variation observed in the Site 770 rocks is a common feature of submarine basaltic rocks and largely depends on the mode of crystallization of the magmas at, or by, the seafloor. Well-developed quench textures with a high but variable $(20 \%-70 \%)$ amount of cryptocrystalline/glassy mesostasis were found in the pillow lava sequences (Units A, $\mathrm{B}$, and $\mathrm{D}$, Table 1). In addition to the skeletal/spherulitic plagioclases and acicular/dendritic clinopyroxenes, the groundmass of the studied pillows is characterized, particularly in Unit A and D, by skeletal/branching olivine. In contrast, the massive lava flow sections (Units $\mathrm{C}$ and $\mathrm{E}$ ) and dolerite sills (Units F and G) generally show groundmasses of subophitic texture with a low, but variable $(0 \%-10 \%)$ amount of mesostasis, typically as intersertal patches.

Although subaphyric to highly phyric types are found, the phenocryst mineralogy of Site 770 rocks is relatively homogeneous. Plagioclase $(1 \%-20 \%)$ is constantly present, and systematically dominant over olivine $(0 \%-10 \%)$ in all the studied samples (plagioclase - olivine phyric basalts), except 
Table 1. Synthetic petrographic description and modal proportion (\% volume) of major phase from Celebes basement rocks.

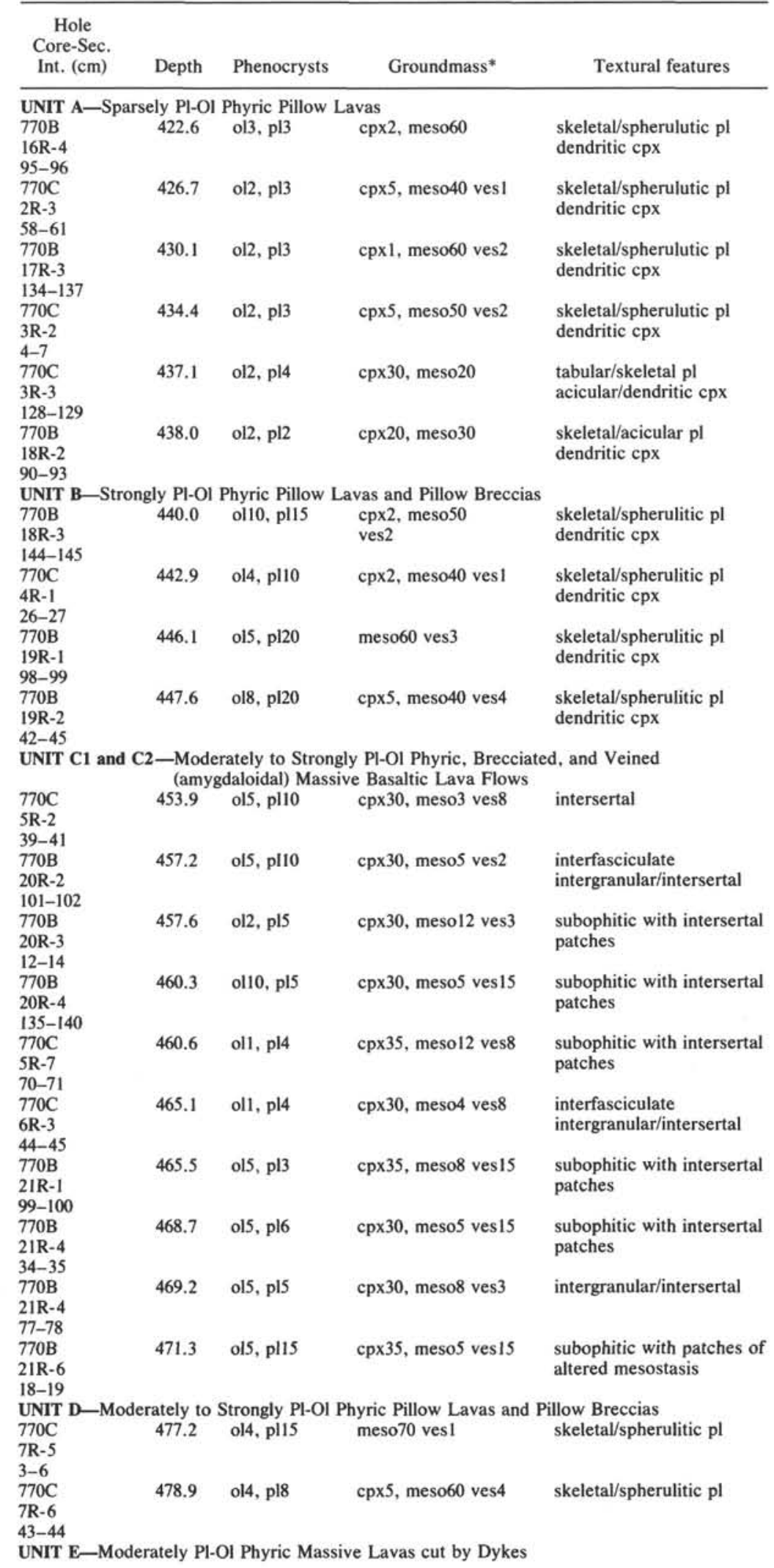


Table 1 (continued).

\begin{tabular}{|c|c|c|c|c|}
\hline $\begin{array}{l}\text { Hole } \\
\text { Core-Sec. } \\
\text { Int. }(\mathrm{cm})\end{array}$ & Depth & Phenocrysts & Groundmass* & Textural features \\
\hline $\begin{array}{l}770 \mathrm{C} \\
9 \mathrm{R}-2 \\
42-48\end{array}$ & 492.7 & ol5, pl4 & \multirow[t]{2}{*}{$\operatorname{cp} \times 35$} & \multirow[t]{2}{*}{ subophitic } \\
\hline UNIT F-Sp & ely $\mathrm{Pl} \mathrm{Ph}$ & ric to Aphyric & & \\
\hline $\begin{array}{l}770 \mathrm{C} \\
10 \mathrm{R}-2 \\
42-43\end{array}$ & 502.4 & pll & cpx40, meso 10 & $\begin{array}{l}\text { subophitic with intersertal } \\
\text { patches }\end{array}$ \\
\hline $\begin{array}{l}770 \mathrm{C} \\
11 \mathrm{R}-1 \\
96-98\end{array}$ & 511.2 & $\mathrm{pl} 2$ & cpx40, mesol0 & $\begin{array}{l}\text { subophitic with intersertal } \\
\text { patches }\end{array}$ \\
\hline \multicolumn{5}{|c|}{ UNIT G-Sparsely to Moderately OI-PI Phyric Dolerite Sill } \\
\hline $\begin{array}{l}770 \mathrm{C} \\
12 \mathrm{R}-2 \\
21-33\end{array}$ & 521.4 & ol15, pl5 & cpx30, meso17 & subophitic \\
\hline $\begin{array}{l}770 \mathrm{C} \\
12 \mathrm{R}-2 \\
38-41\end{array}$ & 521.6 & ol10, pl5 & cpx35, meso5 & \multirow[t]{2}{*}{ subophitic } \\
\hline \multicolumn{4}{|c|}{ UNIT H-Moderately PI-OI Phyric Lavas } & \\
\hline $\begin{array}{l}770 \mathrm{C} \\
12 \mathrm{R}-3 \\
66-67\end{array}$ & 523.3 & ol3, pl12 & cpx30, meso 20 ves 6 & interfasciculate/intersertal \\
\hline
\end{tabular}

the sill of Unit $G$, which can be defined as an olivine $(10 \%-15 \%)$ - plagioclase (about $5 \%$ ) phyric doleritic basalt. $\mathrm{Cr}$-spinel is occasionally found as individual crystals and/or included in olivine and, more rarely, in plagioclase phenocrysts. This is particularly evident in the pillows of Units B and D. Clinopyroxene and Fe-Ti oxides are always confined to the groundmass. The prevailing opaque is Ti-magnetite, but ilmenite has been identified as an additional oxide in most of the massive lavas and dolerite sills.

Textural observation of the quenched rocks indicate that seafloor crystallization invariably took place in the following sequence: olivine + plagioclase, clinopyroxene, Fe-Ti oxides. Spatial relation among phenocrysts indicates that, in the pre-eruptive stage (magma chamber?) the $\mathrm{Cr}$-spinel appears on the liquidus earlier than olivine and plagioclase. In a few occurrences, particularly in Unit B, olivine is found included in plagioclase phenocrysts, but not the other way around. This suggests that, for the less evolved magmas, olivine precedes plagioclase on the liquidus. Sparse plagioclase and olivine clusters as well as plagioclase-olivine glomerocrysts are often present, particularly in the most phyric rocks.

Textural and mineralogical features as well as crystallization sequences of Site 770 rocks are, in all, analogous to typical, relatively primitive mid-ocean- ridge basalts (MORBs).

\section{Alteration}

All the rocks of Site 770 suffered the effects of lowtemperature seafloor alteration that produced a variation in color from dark gray to brownish gray to brownish. This often gives to the rocks a mottled appearance, occasionally even in thin section, particularly in the pillow lava sequences.

Carbonates, essentially calcite, "brown" and "green" clays, and Fe-hydroxides are the most abundant secondary phases. They invariably occur as pseudomorphs after olivine and glassy/cryptocrystalline mesostasis as well as authigenic phases filling veins and vugs. Although no glass has been preserved in the studied samples, the palagonitization (cf. Honnorez, 1978) of the mesostasis has not proceeded to a mature stage. Prevailing alteration minerals are clays. Welldeveloped crystals of phillipsite have been identified in few if any of the samples, with the probable exception of the pillows of Units B and D, where a fibrous/patchy phase with low birefringence and extremely low refringence was found associated with clays and $\mathrm{Fe}$-hydroxides as a devitrification product of the glassy mesostasis.

Olivine relicts were found in only one sample of Unit A (Table 4). Titanomagnetite is largely oxidized, probably to Timaghemite and locally also to secondary Fe-oxides, particularly in the most altered "brown" zones of the pillow lavas (i.e., Unit D). Clinopyroxene and plagioclase are virtually unaltered in all the studied samples. In one strongly brecciated sample from Unit C1 (124-770B-20R-4, 72-79 cm), well-crystallized secondary $\mathrm{K}$-feldspar partially replaces plagioclase.

Petrographic observation does not reveal any significant vertical variation in the distribution of secondary minerals, except perhaps calcite. This mineral is rare in the two upper pillow lava sequences (Units A and B), whereas it suddenly becomes abundant as a space-filling phase in the massive brecciated lavas of Unit $\mathrm{C}$, and persists in variable amounts down to the bottom of the drilled sequence.

Where it is possible to evaluate the deposition sequence of authigenic phases, such as in vugs and vesicles, it is evident that calcite is, in most cases, the last mineral to form. Perhaps its rare occurrence in Units A and B depends on the quicker self-sealing of the voids by clays, due to a higher reactivity to alteration of the abundant glassy mesostasis of the pillow lavas.

The extent of alteration appears to be strongly dependent on the crystallinity of the rocks, which probably drastically reduces the rate of reaction between basalt and seawater, as studied experimentally by Seyfried and Bischoff (1979). In the studied thin sections, the highly oxidized brownish alteration zones are more diffuse in the pillows than in the massive lavas and dolerite sills, independent of their lithostratigraphic position. Brown and green clays are present throughout the Site 770 sequence. The latter are dominant as pseudomorphing phases after olivine and mesostasis, as well as replacing glassy 
inclusions in the plagiociase phenocrysts, in the massive lavas and dolerite sills.

The observed secondary minerals (calcite, Fe-hydroxides, brown and green clays, dominantly smectites and celadonite) and the absence of albite (occasional presence of K-feldspar), chlorites and sphene indicate that the alteration processes took place at a temperature certainly below $140^{\circ}-150^{\circ} \mathrm{C}$ (Seyfried and Bischoff, 1979; Alt et al., 1986).

Although numerous experimental data on element mobilization due to basalt/seawater interaction at low to moderate temperature have been gathered (Seyfried and Bischoff, 1979; Mottl and Holland, 1978; Menzies and Seyfried, 1979; Seyfried and Mottl, 1982), and many studies on mid-ocean ridge basalts altered at low temperature have been performed (Hart et al, 1974; Böhlke et al, 1980; Staudigel et al., 1981; Staudigel and Hart, 1983; Bienvenu et al., 1990) the direction and magnitude of chemical exchange in the altered rocks studied does not follow any simple rule. For instance, important factors such as temperature, water/rock ratio, $\mathrm{pH}$, and oxidation state may easily change in the same structural site during the evolution of halmyrolysis and hydrothermal alteration systems related to the formation and cooling of the oceanic crust, and can therefore produce an complex pattern of element mobilization.

The careful petrographic analysis of secondary phases, together with the recognition that the alteration magnitude in the studied rocks is primarily controlled by the degree of crystallinity, gives important indications for the interpretation of geochemical data on whole rocks.

The major- and trace-element mobility can be inferred by comparing basalts belonging to the same flow unit but showing different degrees of petrographically determined alteration.

Sample 770B-19R, 98-99 cm, is highly oxidized (brown zone), and more altered petrographically than 770B-19R2, $42-45 \mathrm{~cm}$, sampled only $1.5 \mathrm{~m}$ deeper. $\mathrm{K}_{2} \mathrm{O}$ and $\mathrm{P}_{2} \mathrm{O}_{5}$ are significantly enriched in the more altered sample of Unit B $\left(0.14 \%-0.43 \%\right.$ and $0.10 \%-0.15 \%$ respectively). The $\mathrm{P}_{2} \mathrm{O}_{5}$ enrichment may be due to the incorporation of seawater phosphate into secondary ferric oxide, replacing olivine in the highly oxidized zones (cf. Böhlke et al., 1981). In this case, there is also a small but significant (about $10 \%$ ) increase of $\mathrm{TiO}_{2}$. $\mathrm{Nb}$ varies from 2 to $3 \mathrm{ppm}$, but this is obviously within the analytical uncertainty. $\mathrm{V}, \mathrm{Cr}, \mathrm{Zr}, \mathrm{Y}$, and, surprisingly, also $\mathrm{Ni}$ and $\mathrm{Sr}$, appear unaffected. There is also a significant decrease ( $1 \%$ absolute value) of $\mathrm{CaO}$ among major elements.

Another way to evaluate element mobility is to examine bulk composition in relation to depth (Figs. 3 and 4). Because of analytical errors $\mathrm{SiO}_{2}$ and $\mathrm{Na}_{2} \mathrm{O}$ were not plotted (see analytical method). As it is widely recognized that at least $\mathrm{Zr}$, $\mathrm{Nb}$, and $\mathrm{TiO}_{2}$ are virtually immobile during strong lowtemperature alteration even of glassy rocks (Bienvenu et al., 1990; Hart et al., 1974) the ratio between these elements is used to give an initial characterization of magma types. $\mathrm{Ti} / \mathrm{Zr}$ $(75-110)$ and $\mathrm{Zr} / \mathrm{Nb}(>20)$ indicate that all of the studied rocks are consistent with normal MORB (cf. Sun et al., 1979; Saunders et al., 1988; Sun and McDonough, 1989; Le Roex et al., 1989). This result, which is confirmed by the whole trace-element pattern, permits an easier evaluation of element distribution with height. In general, the lithological units also correspond to chemical units.

Unit A (sparsely plagioclase-olivine phyric pillow lavas) is well defined by the homogeneous and distinctly higher $\mathrm{TiO}_{2}$, $\mathrm{P}_{2} \mathrm{O}_{5}, \mathrm{~V}, \mathrm{Zr}, \mathrm{Nb}, \mathrm{Sr}$ contents and $\mathrm{Zr} / \mathrm{Y}$ ratio than in the other lithological types. In contrast, the erratic distribution of $\mathrm{K}_{2} \mathrm{O}$ and $\mathrm{FeO}_{3}$ tot suggests that these elements were mobilized.

Unit B (highly plagioclase-olivine phyric pillow lavas) evidently represents a different magma type. The distribution of $\mathrm{TiO}_{2}(1.18 \%-1.32 \%)$ and $\mathrm{P}_{2} \mathrm{O}_{5}(0.10 \%)$ is relatively homo- geneous, except for one strongly altered sample with higher $\mathrm{P}_{2} \mathrm{O}_{5}(0.15 \%)$ content (seawater phosphate into secondary ferric oxide?). $\mathrm{K}_{2} \mathrm{O}$ is highly variable. Low $\mathrm{TiO}_{2}$ and $\mathrm{P}_{2} \mathrm{O}_{5}$, high $\mathrm{Cr}(404-383 \mathrm{ppm})$, and $\mathrm{Ni}(150-144 \mathrm{ppm})$ indicate a relatively primitive nature of the original magma; mg numbers (58.6-59.5) are relatively low for such high $\mathrm{Cr}$ and $\mathrm{Ni}$ magmas. It is hard to say whether or not this is due to spinel and olivine accumulation. At any rate the comparison, as regards $\mathrm{TiO}_{2}$ and $\mathrm{Ni}$ vs. $\mathrm{MgO}$, of the studied rocks with the spectrum of variation of N-MORB (Fig. 5) indicate that the basalts of Unit $\mathrm{B}$ are too low in $\mathrm{MgO}$ for the given $\mathrm{TiO}_{2}$ and $\mathrm{Ni}$ contents. A possible explanation, also supported by experimental data (Seyfried and Bischoff, 1979) and petrography (Table 1), is that $\mathrm{MgO}$ is leached from the pillow basalts (in this case olivine and glass) during alteration under oxidizing conditions. Analogous reasoning is likely to apply also to the upper pillow lava sequence (Unit A), where the rocks show an anomalously high $\mathrm{Ni} / \mathrm{MgO}$ ratio compared to the maximum variation of normal MORBs (Fig. 5). This is also valid when $\mathrm{Ni}-\mathrm{MgO}$ variation of bach-arc basin basalts from the Mariana Trough and the Lau Basin are taken into consideration (Fig. 5).

Unit C (moderately to highly plagioclase-olivine phyric massive lava flows) is chemically distinguishable into two subunits, $\mathrm{C} 1$ and $\mathrm{C} 2$. The latter shows higher $\mathrm{TiO}_{2}, \mathrm{P}_{2} \mathrm{O}_{5}$ and $\mathrm{Zr}$ contents. $\mathrm{C} 1$ is also transitional (for $\mathrm{Zr}, \mathrm{Y}, \mathrm{V}, \mathrm{Cr}, \mathrm{Sr}$ ) between Unit $\mathrm{B}$ and $\mathrm{C} 2$. $\mathrm{TiO}_{2}$ of Unit $\mathrm{C} 1$ and $\mathrm{C} 2$ shows a relatively small scatter, whereas $\mathrm{K}_{2} \mathrm{O}$ and $\mathrm{Fe}_{2} \mathrm{O}_{3}$ are highly variable. The $\mathrm{MgO} / \mathrm{TiO}_{2}$ ratio of Unit $\mathrm{C}$ is apparently not anomalous among MORBS (Fig. 5), whereas $\mathrm{Ni} / \mathrm{MgO}$ ratio is evidently quite high and generally outside of MORB spectrum (Fig. 5). Whether this is due to olivine accumulation or slight $\mathrm{MgO}$ removal is hard to say. In the case of the massive rocks, it is not necessary to invoke extensive $\mathrm{MgO}$ removal to explain $\mathrm{Mg}$ and $\mathrm{Ni}$ distribution. This is in accordance with petrographic observations, which show a smaller amount of secondary minerals, and with the conclusion of Böhlke et al. (1981) on similar massive rocks from DSDP Site 396B in the North Atlantic. Ubiquitous metastable clinopyroxene and plagioclase as well as minor microcrystalline/glassy mesostasis indicate that $\mathrm{Al}$ and $\mathrm{Ca}$ are probably not too far from the magmatic value, particularly in massive rocks. The high $\mathrm{CaO}$ and $\mathrm{Al}_{2} \mathrm{O}_{3}$ content of Units $\mathrm{B}$ and $\mathrm{C}$ is generally associated with the presence of abundant plagioclase phenocrysts.

Only one or two samples from Units D, E, F, G, and H were studied (Table 1 and Figs. 3 and 4). In general the Ti, Mg, $\mathrm{Ni}$ variation is within the MORB spectrum. This suggests that $\mathrm{MgO}$ removal was not strong below the massive lava sequence of Unit C. Higher incidence of "'green" over "brown" clay, as well as predominance of crystalline rocks, suggest that this might be related to a weaker oxidation, possibly due to a lower water/rock interaction (cf. Seyfried and Bischoff, 1979). It is to be noted that the dolerite sill of Unit F resulted from the intrusion of a relatively evolved magma (Tables 5 and 6; Figs. 3 and 4) approaching the chemical composition of Unit A. These doleritic basalts are the least-altered rocks of the Celebes Basin. Accordingly, concentration of $\mathrm{K}_{2} \mathrm{O}(0.24 \%)$, $\mathrm{Rb}(3.25 \mathrm{ppm})$ and $\mathrm{Cs}(0.05 \mathrm{ppm})$, and even $\mathrm{Li}(9.5 \mathrm{ppm})$, are within the range of evolved fresh N-MORB glasses (cf. Hertogen et al., 1980; Seyfried et al., 1984). Nevertheless, TI is enriched by about a factor of 10 relative to fresh N-MORB glasses (cf. McGoldrick et al., 1979; Hertogen et al., 1980). In general, $\mathrm{Tl}, \mathrm{Cs}$, and $\mathrm{Li}$ as well as $\mathrm{Rb}$ are the most sensitive indicator of rock/sea water interaction at low temperature. The fact that only $\mathrm{Tl}$ appears to be significantly enriched indicates that the effect of low temperature alteration on whole-rock chemistry of the studied doleritic basalt (124$770 \mathrm{C}-10 \mathrm{R}-2,43-47 \mathrm{~cm}$ ) was so weak as to be considered virtually absent. 
CELEBES SEA IGNEOUS ROCKS


Figure 3. Stratigraphic plots for some major elements of Celebes Sea basalts. $\mathrm{mg}=100 \mathrm{Mg} /\left(\mathrm{Mg}+\mathrm{Fe}^{2+}\right) . \mathrm{Fe}_{2} \mathrm{O}_{3} / \mathrm{FeO}^{2}=0.15$. 
G. SERRI ET AL.
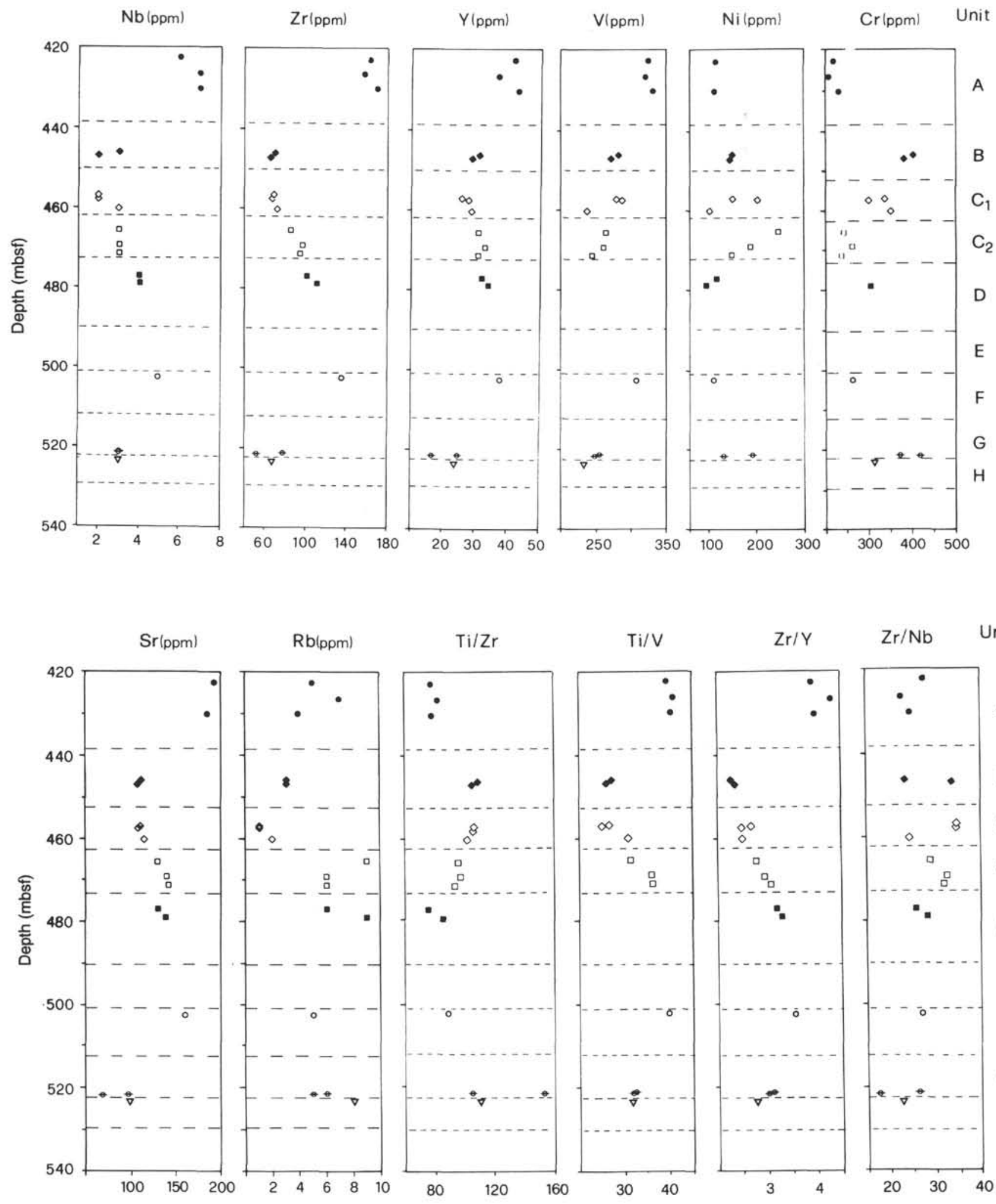

$\mathrm{Zr} / \mathrm{Nb} \quad$ Unit

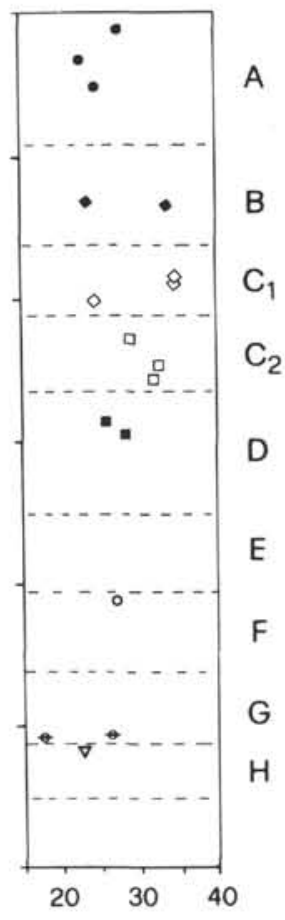

Figure 4. Stratigraphic plots for some trace elements and $\mathrm{Ti} / \mathrm{Zr}, \mathrm{Ti} / \mathrm{V}, \mathrm{Zr} / \mathrm{Y}$, and $\mathrm{Zr} / \mathrm{Nb}$ ratios of Celebes Sea basalts. 

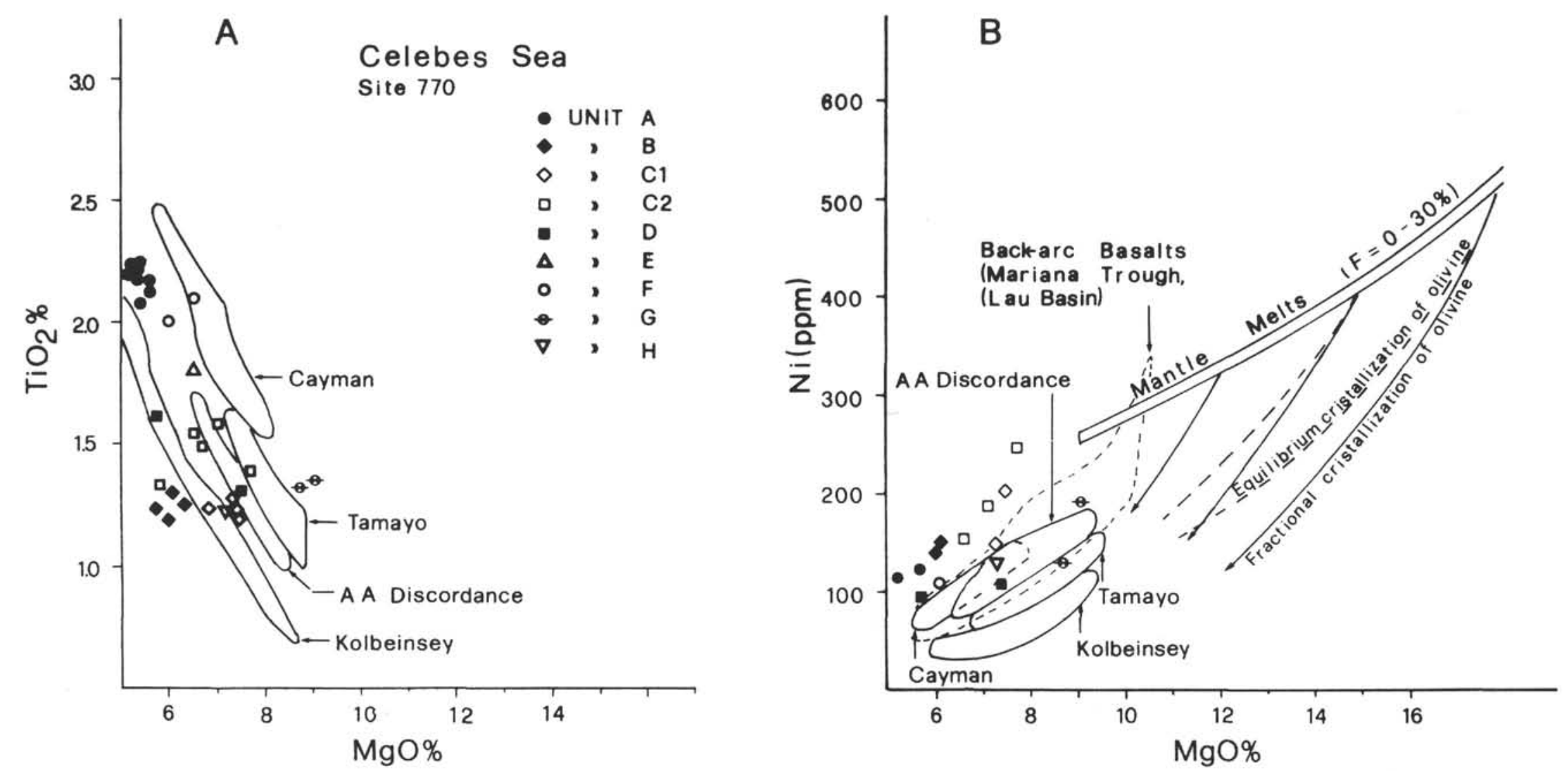

Figure 5. A. $\mathrm{TiO}_{2}$ vs. $\mathrm{MgO}$ and B. Ni vs. $\mathrm{MgO}$ diagrams of Celebes Sea basalts. Fields for rocks from Mid-Cayman Rise, East Pacific Rise southward of Tamayo transform, Australian-Antarctic discordance and Kolbeinsey Ridge after Klein and Langmuir, 1987. Field of Mariana Trough and Lau back-arc basins after Hawkins and Melchior, 1985. 
Element mobilization can also be evaluated by comparing elements that may be enriched by halmyrolis such as $\mathrm{Ce}, \mathrm{Ba}, \mathrm{Th}$, $\mathrm{U}$, and $\mathrm{K}$ with $\mathrm{Nb}$, which is considered geochemically immobile during low-temperature seafloor alteration (cf. Bienvenu et al., 1990; Hart et al., 1974). For these elements, MORB-OIB systematics have recently been studied by Saunders et al. (1988) and are presented in Figure 6 . Th, $\mathrm{Ce}$, and even $\mathrm{Ba}$ show coherent behavior with $\mathrm{Nb}$. This indicates that they were not significantly modified (enriched) by halmyrolis. In contrast, the wide variabilty of the $\mathrm{K} / \mathrm{Nb}$ ratio at constant $\mathrm{Ce} / \mathrm{Nb}$ value indicates that the $\mathrm{K}$ is strongly enriched during the low-temperature alteration suffered by the studied samples. By contrast, the $\mathrm{Th} / \mathrm{Nb}$ ratio is constant, apart from the sample with analytical uncertainties (see analytical methods). This supports the hypothesis of a relative immobility of Th during the alteration of the studied rocks. $\mathrm{U}$, whose concentration is very close to the detection limit of ICP-MS, does not appear, within the analytical uncertainties, to be strongly enriched by alteration, except for the highly oxidized Site 767 basalts.

\section{MINERAL CHEMISTRY}

\section{Site 770}

Petrographically, the rocks of Site 770 are relatively homogeneous (Table 1). They are basalts, with plagioclase and olivine as ubiquitous phenocrysts. Plagioclase and groundmass clinopyroxene are commonly fresh, whereas olivine is altered to secondary minerals in all of the samples except in Unit A, where sporadic relics of olivine microphenocrysts (Fo 83.3) are found (Table 2). The olivine shapes indicate equilibrium growth from the host magma. The calculated $\mathrm{FeO} / \mathrm{MgO}$ ratio $(\mathrm{D}=0.27)$ of the liquid is 1.3 , much lower than the whole-rock $\mathrm{FeO}^{*} / \mathrm{MgO}$ ratio ( 1.7 calculated assuming $\mathrm{Fe}_{2} \mathrm{O}_{3} / \mathrm{FeO}=0.15$ ). As inferred in the alteration chapter, this is mainly due to $\mathrm{MgO}$ removal during halmyrolysis under highly oxidizing conditions. $\mathrm{FeO} / \mathrm{MgO}$ ratios varying between 1.6 and 1.8 allow us to extend this interpretation to the whole of Unit A.

Based on clinopyroxene analyses, Unit A is clearly distinguishable from all the other basaltic units (Table 3; Figure 7), except the pillow lavas of Unit $\mathrm{B} . \mathrm{Ca} / \mathrm{Mg}+\mathrm{Fe}$ ratios of these pillow sequences are significantly higher that the rest of Site 770 clinopyroxenes, which are, however, crystallized with a lower cooling rate either in massive lavas or in dolerite sills. These pyroxenes show a typical subalkaline trend in the pyroxene quadrilateral. Whether or not these differences are due to the cooling rate it is difficult to say. Although some experimental observations (Gamble and Taylor, 1980) show that the partitioning of $\mathrm{Ca}, \mathrm{Mg}$, and $\mathrm{Fe}$ is essentially rateindependent, other results (Lofgren, 1979) indicate that, in relation to increasing cooling rate, a slight increase of $\mathrm{Ca} /$ $\mathrm{Mg}+\mathrm{Fe}$ and signifcant increase of the $\mathrm{Mg} / \mathrm{Fe}$ ratio occurs during quenching of some magma types.

The strong variation of $\mathrm{Al}_{2} \mathrm{O}_{3}$ and $\mathrm{TiO}_{2}$ in quenched pyroxenes from pillow units (Unit $\mathrm{A}, \mathrm{Al}_{2} \mathrm{O}_{3}, 4.3 \%-6.4 \%$; $\mathrm{TiO}_{2}$, $2.4 \%-3.4 \%$. Unit $\mathrm{B}, \mathrm{Al}_{2} \mathrm{O}_{3}, 2.9 \%-7.0 \% ; \mathrm{TiO}_{2}, 1.3 \%-3.0 \%$ ) suggests that the cooling rate was very high, and that therefore some increase of $\mathrm{Ca} / \mathrm{Mg}+\mathrm{Fe}$ and particularly $\mathrm{Fe} / \mathrm{Mg}$ might indeed have taken place.

In conclusion, clinopyroxene composition in terms of quadrilateral elements as well as $\mathrm{TiO}_{2}$ and $\mathrm{Al}_{2} \mathrm{O}_{3}$ appears, in the analyzed rocks, to be more dependent on the kinetics of crystallization rather than the chemistry of parental magmas.

In general the plagioclases show a wide compositional range both in pillow basalts and dolerites (Table 4; Fig. 8). All analyzed units show maximum anorthite content of the plagioclases greater than $84 \%$, reaching the highest value of An $88.5 \%$ in Unit B. Plagioclases from dolerite units (F and G) evidently reach the lowest anorthite content (around 30\% An), while the pillow basalts show groundmass plagioclase with minimum anorthite content around $50 \%$. In the plagioclase rims of Units C2 (massive basalts), anorthite contents between 35 and 40 are attained. Note that the phenocrysts of Unit A (Sample 124-770B-16R-4, 95-96 cm) are slightly more enriched in orthoclase molecules than all the rest of the studied samples from Site 770 at the same anorthite content. This suggests a slightly higher $\mathrm{K}_{2} \mathrm{O}$ content in the parental melt in this unit.

$\mathrm{MgO}$ and iron calculated as $\mathrm{Fe}_{2} \mathrm{O}_{3}$ are found as minor elements (less than $1 \%$ ) in all the analyzed crystals. $\mathrm{FeO}$ (and $\mathrm{K}_{2} \mathrm{O}$ ) are positively correlated with anorthite content as commonly observed in typical MORB (Ayuso et al., 1976). In absolute value, $\mathrm{Fe}$ vs. Na cation variation is very similar to plagioclase from DSDP Leg 64 basalts (cf. Perfit and Fornari, 1983). The variation of $\mathrm{MgO}$ is also typical of MORB plagioclase, with the classic $\mathrm{Mg}$ drop which is observed in this case at about $60 \%$ An content. Whether this is due to the onset of clinopyroxene crystallization (Ayuso et al., 1976) or crystallochemical effects (Perfit and Fornari, 1983) is not clear. However, the ubiquitous absence of clinopyroxene phenocrysts and the $\mathrm{MgO}$ drop being confined to groundmass plagioclases and to the rim of phenocrysts does not allow us to exclude the clinopyroxene effect.

Spinels reveal a rather uniform compositional range (Table 2). In Figure 9 they plot well inside the fields for MORB.

\section{Site 767}

The single sample studied from Site 767 is an altered, finegrained olivine- basalt. The rock, which shows a pseudo-spinifex texture, is characterized by chain-like olivine up to $0.5 \mathrm{~cm}(15 \%)$, and has fasciculated, fan-shaped spherulitic plagioclase $(30 \%)$ intergrown with skeletal dendritic clinopyroxene (20\%). Groundmass olivine also shows branching texture. Vesicles $(2 \%)$ are filled with clays, calcite, and Fe-hydroxides. The same minerals replaced the glassy/criptocrystalline mesostasis (30\%). Olivine is dominantly replaced by Fe-hydroxides. The low-temperature alteration evidently took place under highly oxidizing conditions as indicated by the variable brownish color that gives the rocks a mottled appearance.

\section{GEOCHEMISTRY}

High-quality analyses have been performed on eight selected samples, seven of which come from different stratigraphic levels within the two holes of Site 770. At Site 767 the basement was drilled only for a few centimeters; therefore, only one sample has been analyzed.

Major-element analyses of 29 samples from Holes 770B, $770 \mathrm{C}$, and one from Hole 767 have been reported in Table 5. Trace-element analyses determined in various laboratories on the same samples are reported in Table 6 .

A general overview of the effects of low-temperature seafloor alteration on the whole geochemistry is given in the petrography chapter, alteration section.

Abundance and ratios between incompatible elements, which are widely considered to be immobile or weakly affected by seawater rock alteration processes (cf. Hart et al., 1974), show that all Celebes basement rocks are within the range of variation of MORBs (Tables 5 and 6). Relatively high content of compatible trace elements, such as $\mathrm{Ni}$ and $\mathrm{Cr}$, indicate that these rocks represent nearly primitive or weakly fractionated basaltic magmas despite generally low $\mathrm{MgO}$ contents (5.2\%-7.7\%; Table 5), largely due to removal during halmyrolysis.

Chondrite-normalized REE patterns (Fig. 10A) allow us to classify the studied samples as normal MORB. It is evident that the basalt of the upper part of Unit A, as also shown by the mineral chemistry, is a distinctly different magma type. 

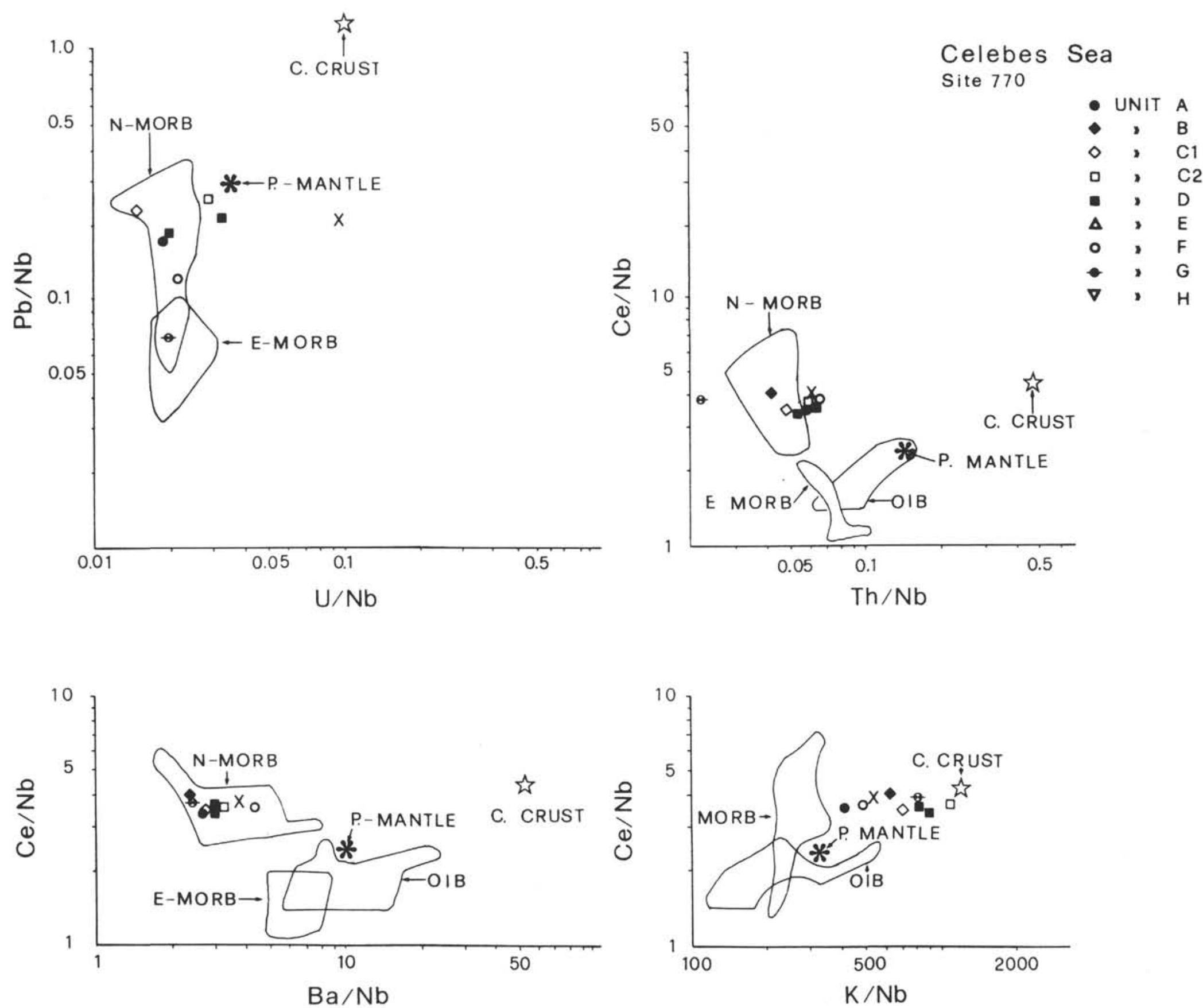

Figure 6. $\mathrm{Pb} / \mathrm{Nb}$ vs. $\mathrm{U} / \mathrm{Nb}, \mathrm{Ce} / \mathrm{Nb}$ vs. Th/Nb, $\mathrm{Ce} / \mathrm{Nb}$ vs. $\mathrm{Ba} / \mathrm{Nb}$, and $\mathrm{Ce} / \mathrm{Nb}$ vs. $\mathrm{K} / \mathrm{Nb}$ of Celebes Sea basalts. Field of N-MORB, E-MORB, and ocean island basalts (OIB) are reported for comparison (after Saunders et al., 1988). Averages for bulk continental crust (Weaver and Tarney, 1984) and primordial mantle estimates (Sun, 1980) are also indicated. The cross identifies the Hole $767 \mathrm{C}$ basalt. 
Table 2. Representative microprobe analyses (wt\% oxide) and atomic proportions of olivine (ol) and $\mathrm{Cr}$-spinel (sp) from Celebes basement rocks. $\mathrm{Fe}^{3+} / \mathrm{Fe}^{2+}$ partitioning is according to charge balance.

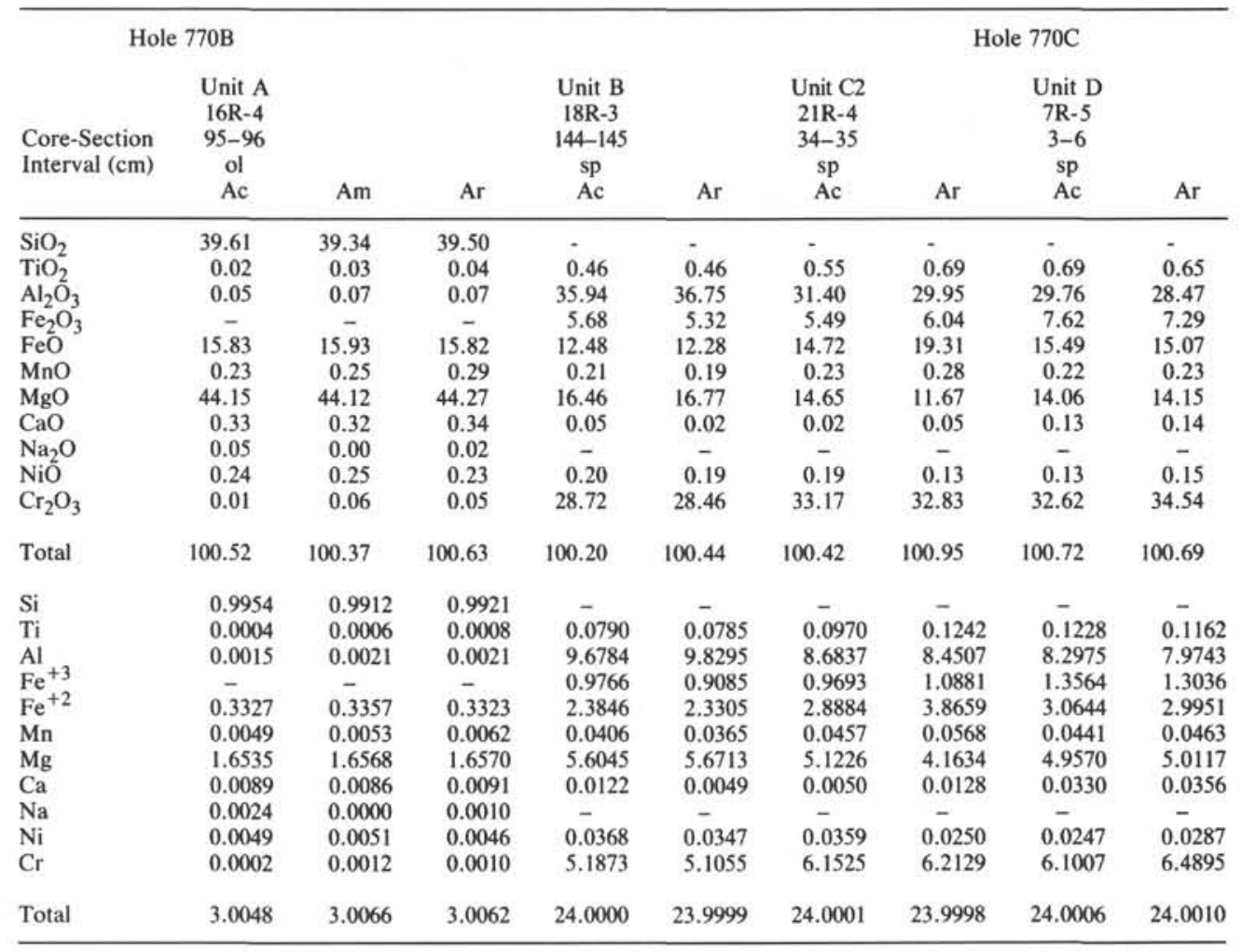

Abbreviations: c, crystal core; $\mathrm{m}$, crystal middle; $\mathrm{r}$, crystal rim.

High $\mathrm{Zr} / \mathrm{Nb}$ ratio, between 25 and 35 , rules out the affinity of this magma with transitional MORB (Le Roex et al., 1989). The MORB-normalized patterns (Fig. 10B) of Samples 124770B-21R-6, 18-19 cm and 124-767C-12R, CC, 36-39 cm, show an anomalous enrichment of $\mathrm{K} 20$ and $\mathrm{Rb}$, due to the low-temperature alteration.

A careful examination of the REE and incompatible element patterns shows increasing $\mathrm{La} / \mathrm{Sm}, \mathrm{La} / \mathrm{Yb}, \mathrm{Zr} / \mathrm{Y}, \mathrm{Nb} / \mathrm{Y}$, and $\mathrm{Th} / \mathrm{Yb}$ with increasing $\mathrm{Th}, \mathrm{Nb}$, and $\mathrm{Ce}$. This is compatible with different degrees of melting of the same mantle source.

The apparently high $\mathrm{Ce}$ and $\mathrm{P}$ abundances relative to a hypothetical baseline drawn between $\mathrm{Zr}$ and $\mathrm{Nb}$ (Fig. 10) cannot be considered indicative of a subduction-related enrichment, for different reasons.

1. The $\mathrm{Ce} / \mathrm{Nb}$ (Fig. 6) and $\mathrm{Ce} / \mathrm{Zr}$ ratios are well within the range of MORBs. The variation of the $\mathrm{Ce} / \mathrm{Zr}$ ratio $(0.106-0.143$, ICP-MS data; 0.099-0.127, on the basis of XRF $\mathrm{Zr}$ data) is within the range of normal MORB from southwest Indian Ridge (0.108-0.157, Le Roex et al., 1983) and comparable to N-MORB from various oceans $(0.102-0.123$, Sun et al., 1979; N-MORB average of $\mathrm{Ce} / \mathrm{Zr}=0.115$, Hofmann, 1988).

2. As shown by numerous authors (cf. Pearce, 1982; Beccaluva et al., 1984), Th is much more sensitive than Ce and $\mathrm{P}$ to subduction-zone enrichment. Evidently the absence of Th enrichment in the Celebes basalts suggests that the very weak $\mathrm{P}$ and $\mathrm{Ce}$ positive anomaly shown in Figure 10 does not represent the signature of a subduction-related component.

A synthesis of the most relevant geochemical features is given in a diagram (Fig. 11) taken from Beccaluva et al., 1984, where the relative variation of $\mathrm{Th}, \mathrm{Nb}$, and $\mathrm{Zr}$ of the most common magmas from subduction- and nonsubduction-related settings are reported. All the samples from the Celebes basement fall within the array of basic lavas from nonsubduction settings, perfectly overlapping the N-MORB field. This is also evident in the $\mathrm{Ce}-, \mathrm{Th}-, \mathrm{Ba}-$, and $\mathrm{Pb}$-normalized to $\mathrm{Nb}$ diagrams (Fig. 6) and in the $\mathrm{Zr} / \mathrm{Y}$ vs. $\mathrm{Zr} / \mathrm{Nb}$ plot of Figure 12.

The $\mathrm{Sr}$ isotopic composition of eight samples, many of which were analyzed in duplicate, ranges between 0.70324 and 0.70350 (Table 6). One sample shows a ratio as high as 0.70483 , which was reduced to 0.70344 by $6.5 \mathrm{~N} \mathrm{HCl}$ cold leaching. ${ }^{143} \mathrm{Nd} /{ }^{144} \mathrm{Nd}$ ratios measured in three samples of Unit $\mathrm{A}, \mathrm{B}$, and $\mathrm{C} 1$ gave nearly homogeneous values in the range 0.51291-0.51298. In the Sr-Nd isotopic diagram (Fig. 13), the Celebes basalts plot within the mantle array, but outside the field of Atlantic and Pacific MORBs. The obtained values are typical of some back-arc basin basalts, such as those of the Lau Basin (Volpe et al., 1988) and of MORBs from the Indian Ocean (Mahoney et al., 1989).

\section{CONCLUSIONS}

The middle Eocene oceanic basement of the Celebes Sea, drilled at Sites 767 and 770 during ODP Leg 124, consists of eight units made of basaltic lava and doleritic sills, all of which suffered various degree of low-temperature seafloor alteration, at temperatures certainly below $140^{\circ}-150^{\circ} \mathrm{C}$. Secondary mobilization generally involved $\mathrm{Tl}, \mathrm{Cs}, \mathrm{Li}, \mathrm{Rb}, \mathrm{K}$, and, to a lesser extent, $\mathrm{Mg}, \mathrm{Ca}, \mathrm{Na}$, and, occasionally, $\mathrm{P}$, whereas the most crystalline samples appear to be only slightly affected by chemical changes.

Textural and mineralogical features as well as the crystallization sequence (olivine, plagioclase, clinopyroxene, $\mathrm{Fe}-\mathrm{Ti}$ oxides) of Site 770 basement rocks are, in all, analogous to typical mid-ocean-ridge basalts. All of the studied rocks are geochemically within the spectrum of normal MORB compositional variation. Relatively high content of compatible trace elements, such as $\mathrm{Ni}$ and $\mathrm{Cr}$, indicate that these rocks 
Table 3. Representative microprobe analyses (wt. \% oxide) and atomic proportions of pyroxenes from Celebes basement rocks, $\mathrm{Fe}^{3+} / \mathrm{Fe}^{2+}$ partitioning according to Papike et al., 1974.



Abbreviations: c, crystal core; m, crystal middle; r, crystal rim; g, crystal in the groundmass; mph-c, mph-r, microphenocryst core and rim, respectively. 


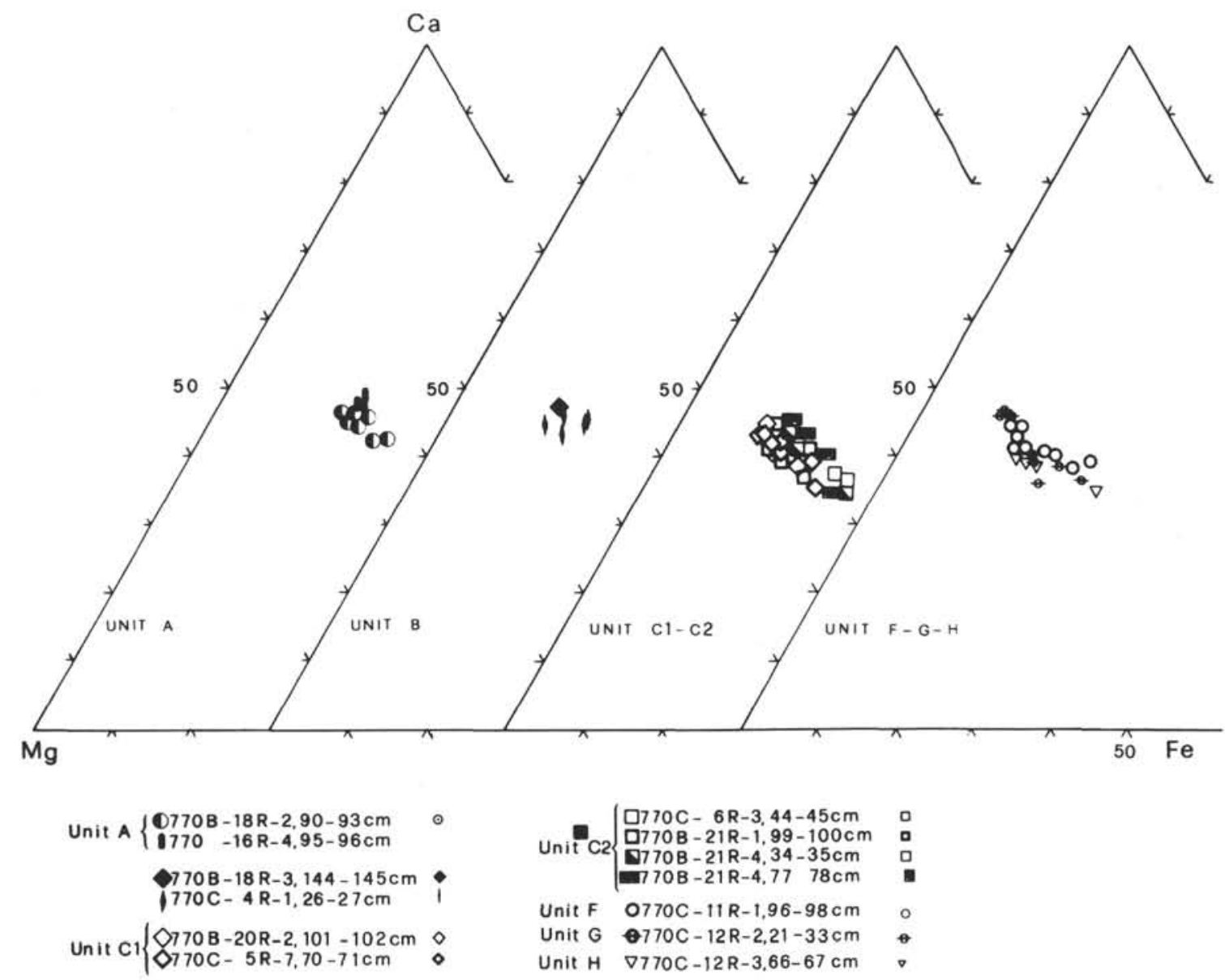

Figure 7. Pyroxene compositions of Celebes basement rocks in the Ca-Mg-Fe diagram (atoms \%). Large and small symbols represent core and rim of the same crystal, respectively.

represent nearly primitive or weakly fractionated basaltic magmas, despite the relatively low $\mathrm{MgO}$ contents in many samples, largely due to removal during halmyrolysis.

The $\mathrm{Sr}$ and Nd isotope ratios of the Celebes basalts plot on the mantle array $\left({ }^{87} \mathrm{Sr} /{ }^{87} \mathrm{Sr} 0.70324-0.70348\right.$ with ${ }^{143} \mathrm{Nd} /{ }^{144} \mathrm{Nd}$ 0.51298-0.51291) outside the field of Atlantic and Pacific MORBs. Similar Sr and Nd isotope ratios are typical of Indian Ocean MORBs and also of some back-arc basalts, such as those of Lau Basin.

The mantle source of Celebes basement basalts does not show a detectable influence of a subduction-related component. Therefore, the geochemical and isotopic data so far obtained on the Celebes basement rocks does not allow a clear discrimination between mid-ocean ridge and back-arc settings.

\section{ACKNOWLEDGMENTS}

We benefited from the comments of A. D. Saunders and an anonymous reviewer. We also thank E. Saccani for cooperation in the analytical work.

\section{REFERENCES}

Alt, J. C., Honnorez, J., Laverne, C., and Emmermann, R., 1986. Hydrothermal alteration of a $1 \mathrm{~km}$ section through the upper oceanic crust, Deep Sea Drilling Project Hole 504B: mineralogy, chemistry, and evolution of seawater-basalt interactions. J. Geophys. Res., 91:10309-10335.
Ayuso, R. A., Bence, A. E., and Taylor, S. R., 1976. Upper Jurassic tholeiitic basalts from DSDP Leg 11. J. Geophys. Res., 81:43054325.

Beccaluva, L., Di Girolamo, P., and Serri, G., 1984. High-K Calkalkalic, Shoshonitic and Leucitic Volcanism of Campania (Roman Province, Southern Italy): Trace Elements Constraints on the Genesis of an Orogenic Volcanism in a Post-collisional Extension Setting: Pisa (Cursi C.), 1-47.

Bence, A. E., and Albee, A. L., 1968. Empirical correction factors for the electron microanalysis of silicates and oxides. J. Geol., 76:382-403.

Bienvenu, P., Bougault, H., Joron, J. L., Treuil, M., and Dmitriev, L., 1990. MORB alteration: rare-earth element/non-rare-earth hygromagmaphile element fractionation. Chem. Geol., 82:1-14.

Böhlke, J. K., Honnorez, J., and Honnorez-Guerstein, B. M., 1980. Alteration of basalts from Site 396B, DSDP: petrographic and mineralogic studies. Contrib. Mineral. Petrol., 73:341-364.

Böhlke, J. K., Honnorez, J., Honnorez-Guerstein, B. M., Muehlenbachs, K., and Petersen, N., 1981. Heterogeneous alteration of the upper oceanic crust: correlation of rock chemistry, magnetic properties, and 0 isotope ratios with alteration pattern in basalts from Site 396B, DSDP. J. Geophys. Res., 86:7935-7950.

Bryan, W. B., Thompson, G., and Ludden J. N., 1981. Compositional variation in normal MORB from $22^{\circ}-25^{\circ} \mathrm{N}$ : Mid-Atlantic Ridge and Kane fracture zone. J. Geophys. Res., 86:11815-11836.

Crawford, A. J., Beccaluva, L., Serri, G., and Dostal, J., 1986. Petrology, geochemistry and tectonic implications of volcanics dredged from the intersection of the Yap and Mariana trenches. Earth Planet. Sci. Lett., 80:265-280. 
DePaolo, D., 1988. Neodymium Isotope Geochemistry: An Introduction: Berlin (Springer-Verlag).

Faure, G., 1986. Principles of Isotope Geology: New York (Wiley).

Gamble, R. P., and Taylor, L. A., 1980. Crystal/liquid partitioning in augite: effects of cooling rate. Earth Planet. Sci. Lett., 47:21-33.

Hart, S. R., 1988. Heterogeneous mantle domains: signatures, genesis and mixing chronologies. Earth Planet. Sci. Lett., 90:273-296.

Hart, S. R., Erlank, A. J., and Kable, J. D., 1974. Sea floor basalt alteration: some chemical and $\mathrm{Sr}$ isotopic effects. Contrib. Mineral. Petrol., 44:219-230.

Hawkins, J. W., and Melchior, J. T., 1985. Petrology of Mariana Trough and Lau Basin basalts. J. Geophys. Res., 90:11431-11468.

Hertogen, J., Janssens, M.-J., and Palme, H., 1980. Trace elements in ocean ridge basalt glasses: implications for fractionations during mantle evolution and petrogenesis. Geochim. Cosmochim. Acta., 44:2125-2143.

Hofmann, A. W., 1988. Chemical differentiation of the Earth: the relationship between mantle, continental crust, and oceanic crust. Earth Planet. Sci. Lett., 90:297-314.

Honnorez, J., 1978. Generation of phillipsites by palagonitazion of basaltic glass in sea water and the origin of K-rich deep-sea sediments. In Sand, L. B., and Mumpton, F. A. (Eds.), Natural Zeolites: Occurrence, Properties and Use: New York, 245-258.

Jenner, G. A., Longerich, H. P., Jackson, S. E., and Fryer, B. J., 1990. ICP-MS: a powerful tool for high-precision trace-element analysis in earth sciences: evidence from analysis of selected U.S.G.S. reference samples. Chem. Geol., 83:133-148.

Klein, E. M., and Langmuir, C. H., 1987. Global correlations of ocean ridge chemistry with axial depth and crustal thickness. J. Geophys. Res., 92:8089-8115.

Lee, C. S., and McCabe, R., 1986. The Banda Celebes Sulu Basins: a trapped piece of Cretaceous Eocene oceanic crust? Nature, 322:51-54

Leg 124 Scientific Drilling Party, 1989. Leg 124 researchers drill marginal basins. Geotimes, 34:15-17.

Le Roex, A. P., Dick, H.J.B., and Fisher, R. L., 1989. Petrology and geochemistry of MORB from $25^{\circ} \mathrm{E}$ to $46^{\circ} \mathrm{E}$ along the Southwest Indian Ridge: evidence for contrasting styles of mantle enrichment. J. Petrol., 30:947-986.

Le Roex, A. P., Dick, H.J.B., Reid, A. M., Frey, F. A., Erlank, A. J., and Hart, S. R., 1985. Petrology and geochemistry of basalts from the American-Antarctic Ridge, Southern Ocean: implications for the westward influence of the Bouvet mantle plume. Contrib. Mineral. Petrol., 90:367-380.

Le Roex, A. P., Erlank, A. J., and Needham, H. D., 1981. Geochemical and mineralogical evidence for the occurrence of at least three distinct magma types in the "Famous" Region. Contrib. Mineral. Petrol., 77:24-37.

Le Roex, A. P., Reid, A. M., Frey, F. A., and Hart, S. R., 1983. Geochemistry, mineralogy and petrogenesis of lavas erupted along the southwest Indian Ridge between the Bouvet triple junction and 11 degrees E. J. Petrol., 24:267-318.

Lofgren, G. E., 1979. Dynamic Crystallization and Devetrification Studies 1970-1978: Houston (NASA, Lyndon B. Johnson Space Center).

Mahoney, J. J., Natland, J. H., White, W. M., Poreda, R., Fisher, R. L., and Baxter, A. N., 1989. Isotopic and geochemical provinces of the western Indian Ocean spreading centers. J. Geophys. Res., 94:4033-4052.

McGoldrick, P. J., Reid, R. K., and Scott, B. B., 1979. Thallium: a sensitive indicator or rock/seawater interaction and of sulfur saturation of silicate melts. Geochim. Cosmochim. Acta, 43:1303-1311.

Menzies, M. A., and Seyfried, W. E., 1979. Basalt-seawater interaction: trace element and strontium isotopic variation in experimentally altered glassy basalt. Earth Planet. Sci. Lett., 44:463-472.

Mottl, M. J., and Holland, H. D., 1978. Chemical exchange during hydrothermal alteration of basalt by seawater. I. Experimental results for major and minor components of seawater. Geochim. Cosmochim. Acta, 42:1103-1115.

Papike, J. J., Cameron, K. L., and Baldwin, K., 1974. Amphiboles and pyroxenes: characterization of other than quadrilateral com- ponents and estimates of ferric iron from microprobe data. Geol. Soc. Am. Abstr. Programs, 6:1053-1054.

Pearce, J. A., 1982. Trace element characteristics of lavas from destructive plate boundaries. In Thorpe, R. S. (Ed.), Andesites: Orogenic Andesites and Related Rocks: New York (Wiley), 525-548.

Perfit, M. R., and Fornari, D. J., 1983. Geochemical studies of abyssal lavas recovered by DSRV Alvin from eastern Galapagos Rift, Inca Transform, and Ecuador Rift. 2. Phase chemistry and crystallization history. J. Geophys. Res., 88:10530-10550.

Price, R. C., Johnson, L. E., and Crawford, A. J., 1990. Basalts of the North Fiji Basin: the generation of back arc basin magmas by mixing of depleted and enriched mantle sources. Contrib. Mineral. Petrol., 105:106-121.

Rangin, C., 1989. The Sulu Sea, a back arc basin setting within a Neogene collision zone. Tectonophysics, 161:119-141.

Rangin, C., Silver, E. A., von Breymann, M. T., et al., 1990. Proc. $O D P$, Init. Repts., 124: College Station, TX (Ocean Drilling Program).

Saunders, A. D., and Tarney, J., 1984. Geochemical characteristics of basaltic volcanism within back-arc basins. In Kokelaar, B. P., and Howells, M. F. (Eds.), Marginal Basin Geology. Volcanic and Associated Sedimentary and Tectonic Processes. London (Blackwell), 59-73.

Saunders, A. D., Norry, M. J., and Tarney, J. 1988. Origin of MORB and chemically depleted mantle reservoirs: trace elements constraints. J. Petrol. (Spec. Lithospheric Iss.), 415-445.

Seyfried, W. E., Janecky, D. R., and Mottl, M. J., 1984. Alteration of oceanic crust: implications for geochemical cycles of lithium and boron. Geochim Cosmochim. Acta, 48:557-569.

Seyfried, W. E., Jr., and Bischoff, J. L., 1979. Low temperature basalt alteration by seawater: an experimental study at $70^{\circ} \mathrm{C}$ and $150^{\circ} \mathrm{C}$. Geochim. Cosmochim. Acta, 43:1937-1947.

Seyfried, W. E., Jr., and Mottl, M. J., 1982. Hydrothermal alteration of basalt by seawater under seawater-dominated conditions. Geochim. Cosmochim. Acta, 46:985-1002.

Staudigel, H., and Hart, S. R., 1983. Alteration of basaltic glass: mechanisms and significance of the oceanic crust-seawater budget. Geochim. Cosmochim. Acta, 47:337-350.

Staudigel, H., Muehlenbachs, K., Richardson, S. H., and Hart, S. R., 1981. Agents of low temperature ocean crust alteration. Contrib. Mineral. Petrol., 77:150-157.

Sun, S. S., 1980. Lead isotopic study of young volcanic rocks from mid-ocean ridges, ocean islands and island arcs. Philos. Trans. $R$. Soc. London, A297:409-445.

Sun, S.-S., and McDonough, W. F., 1989. Chemical and isotopic systematics of oceanic basalts: implications for mantle composition and processes. In Saunders, A. D., and Norry, M. J. (Eds.), Magmatism in the Ocean Basins. Geol. Soc. Spec. Publ. London, 42:313-345.

Sun, S.-S., Nesbitt, R. W., and Sharaskin, A. Y., 1979. Geochemical characteristics of mid-ocean ridge basalts. Earth Planet. Sci. Lett., 44:119-138.

Taylor, R. S., and Gorton, M. P., 1977. Geochemical application of spark source mass spectrography - III. Element sensitivity precision and accuracy. Geochim. Cosmochim. Acta., 41:1375-1380.

Volpe, A. M., Macdougall, J. D., and Hawkins, J. W., 1988. Lau Basin basalts (LBB): trace element and Sr-Nd isotopic evidence for heterogeneity in back arc basin mantle. Earth Planet. Sci. Lett., 90:174-186.

Weaver, B. L., and Tarney, J., 1984. Estimating the composition of the continental crust: an empirical approach. Nature, 310:575-577.

Wood, D. A., Tarney, J., Varet, J., Saunders, A. D., Bougault, H., Joron, J.-L., Treuil, M., and Cann, J. R., 1979. Geochemistry of basalts drilled in the North Atlantic by IPOD Leg 49: implications for mantle heterogeneity. Earth Planet. Sci. Lett., 42:77-97.

Date of initial receipt: 4 June 1990

Date of acceptance: 17 June 1991

Ms 124B-160 
Table 4. Representative microprobe analyses (wt \% oxide) and atomic proportions of plagioclases from Celebes basement rocks.

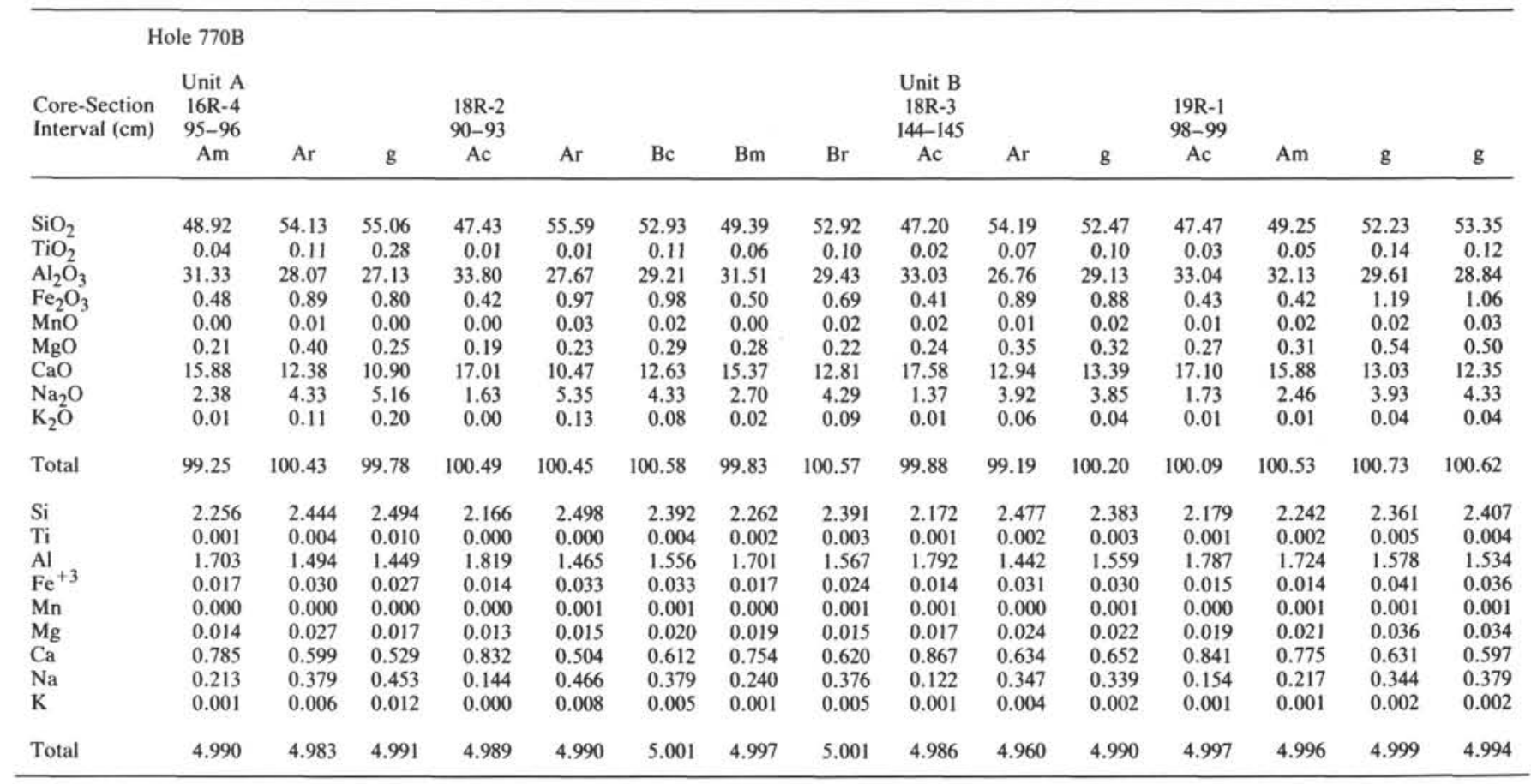

Hole $770 \mathrm{~B}$

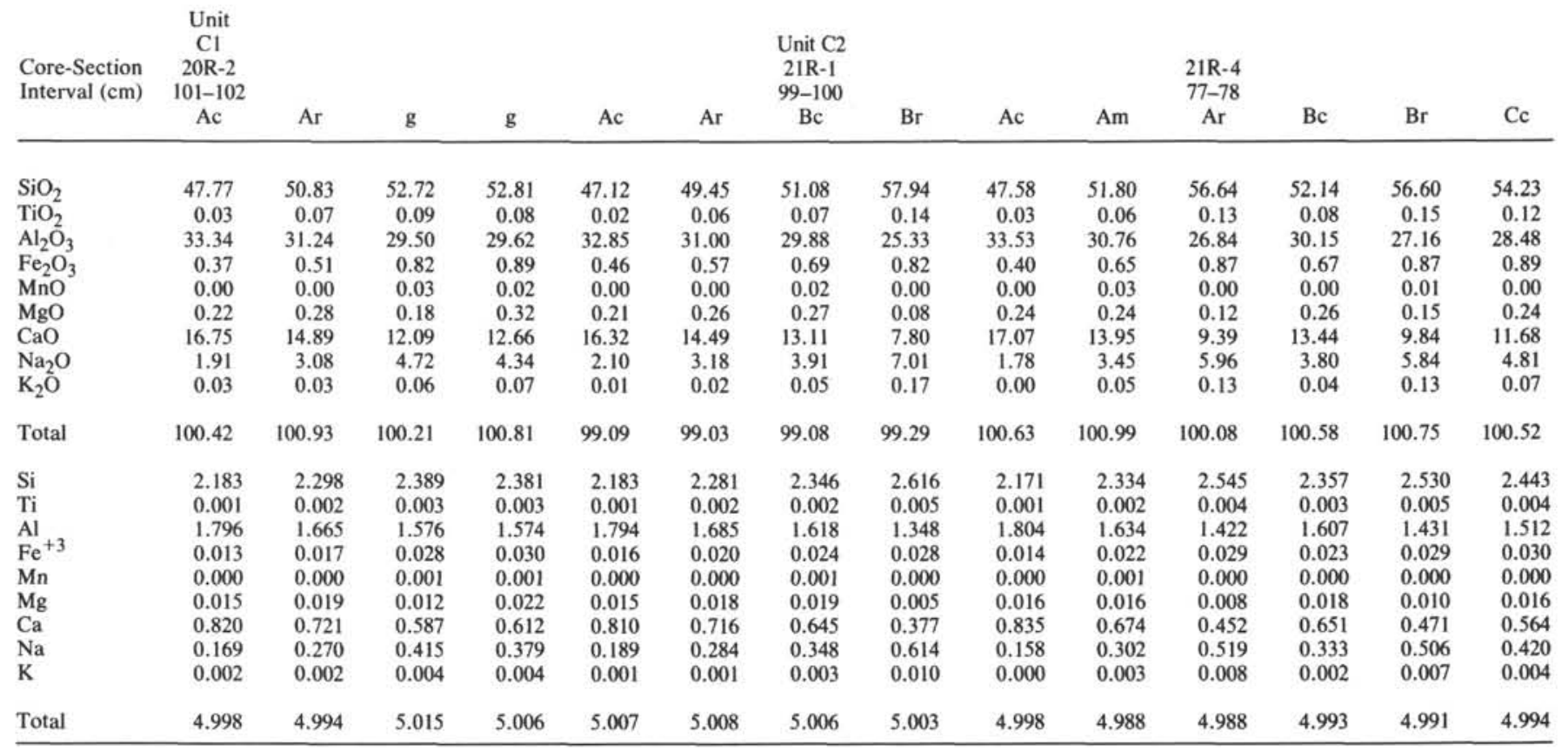

Abbreviations: c, crystal core; m, crystal middle; r, crystal rim; g, crystal in the groundmass; mph-c, mph-r, microphenocryst core and rim, respectively. 
Table 4 (continued).

\begin{tabular}{|c|c|c|c|c|c|c|c|c|c|c|c|c|c|}
\hline \multirow{5}{*}{$\begin{array}{l}\text { Core-Section } \\
\text { Interval }(\mathrm{cm})\end{array}$} & \multicolumn{13}{|l|}{ Hole $770 \mathrm{C}$} \\
\hline & & \multirow{3}{*}{$\begin{array}{c}\text { Unit } \mathrm{Cl} \\
5 \mathrm{R}-7 \\
70-71\end{array}$} & & \multicolumn{3}{|l|}{ Unit D } \\
\hline & 4 R-1 & & & & & & & $6 \mathrm{R}-3$ & & & $7 R-5$ & & \\
\hline & $26-27$ & & & & & & & $44-45$ & & & $3-6$ & & \\
\hline & Ac & $\mathrm{Ar}$ & $\mathrm{Bc}$ & $\mathrm{Bm}$ & $\mathrm{Br}$ & g & $\mathrm{Ar}$ & $\mathrm{g}$ & Ac & $\mathrm{Ar}$ & Ac & \multicolumn{2}{|l|}{$\mathrm{Ar}$} \\
\hline $\mathrm{SiO}_{2}$ & 49.46 & 53.93 & 47.41 & 46.12 & 54.31 & 52.80 & 53.69 & 52.50 & 48.46 & 52.98 & 49.19 & 52.43 & \\
\hline $\mathrm{TiO}_{2}$ & 0.04 & 0.08 & 0.04 & 0.04 & 0.09 & 0.10 & 0.10 & 0.06 & 0.04 & 0.06 & 0.03 & 0.07 & \\
\hline $\mathrm{Al}_{2} \mathrm{O}_{3}$ & 31.38 & 28.21 & 32.83 & 33.90 & 27.59 & 29.07 & 28.63 & 29.06 & 32.93 & 28.91 & 31.44 & 29.12 & \\
\hline $\mathrm{Fe}_{2} \mathrm{O}_{3}$ & 0.47 & 0.89 & 0.41 & 0.38 & 0.57 & 0.84 & 0.80 & 0.75 & 0.39 & 0.78 & 0.43 & 0.88 & \\
\hline $\mathrm{MnO}^{3}$ & 0.01 & 0.00 & 0.00 & 0.00 & 0.04 & 0.01 & 0.00 & 0.00 & 0.00 & 0.01 & 0.02 & 0.00 & \\
\hline $\mathrm{MgO}$ & 0.31 & 0.48 & 0.27 & 0.20 & 0.38 & 0.39 & 0.19 & 0.28 & 0.26 & 0.29 & 0.31 & 0.36 & \\
\hline $\mathrm{CaO}$ & 14.92 & 12.39 & 16.27 & 17.25 & 11.79 & 12.63 & 11.76 & 13.27 & 16.82 & 13.24 & 15.76 & 13.48 & \\
\hline $\mathrm{Na}_{2} \mathrm{O}$ & 2.73 & 4.33 & 1.76 & 1.23 & 4.35 & 4.19 & 4.88 & 3.94 & 2.02 & 4.03 & 2.51 & 3.78 & \\
\hline $\mathrm{K}_{2} \mathrm{O}$ & 0.01 & 0.05 & 0.01 & 0.01 & 0.07 & 0.05 & 0.08 & 0.06 & 0.01 & 0.05 & 0.01 & 0.05 & \\
\hline Total & 99.33 & 100.36 & 99.00 & 99.13 & 99.19 & 100.08 & 100.13 & 99.92 & 100.93 & 100.35 & 99.70 & 100.17 & \\
\hline $\mathrm{Si}$ & 2.273 & 2.436 & 2.193 & 2.137 & 2.473 & 2.396 & 2.431 & 2.389 & 2.203 & 2.400 & 2.258 & 2.382 & \\
\hline $\mathrm{Ti}$ & 0.001 & 0.003 & 0.001 & 0.001 & 0.003 & 0.003 & 0.003 & 0.002 & 0.001 & 0.002 & 0.001 & 0.002 & \\
\hline $\mathrm{Al}$ & 1.700 & 1.502 & 1.790 & 1.852 & 1.481 & 1.555 & 1.528 & 1.559 & 1.764 & 1.544 & 1.701 & 1.559 & \\
\hline $\mathrm{Fe}^{+3}$ & 0.016 & 0.030 & 0.014 & 0.013 & 0.020 & 0.029 & 0.027 & 0.026 & 0.013 & 0.027 & 0.015 & 0.030 & \\
\hline $\mathrm{Mn}$ & 0.000 & 0.000 & 0.000 & 0.000 & 0.002 & 0.000 & 0.000 & 0.000 & 0.000 & 0.000 & 0.001 & 0.000 & \\
\hline $\mathrm{Mg}$ & 0.021 & 0.032 & 0.019 & 0.014 & 0.026 & 0.026 & 0.013 & 0.019 & 0.018 & 0.020 & 0.021 & 0.024 & \\
\hline $\mathrm{Ca}$ & 0.735 & 0.600 & 0.806 & 0.857 & 0.575 & 0.614 & 0.570 & 0.647 & 0.819 & 0.643 & 0.775 & 0.656 & \\
\hline $\mathrm{Na}$ & 0.243 & 0.379 & 0.158 & 0.111 & 0.384 & 0.369 & 0.428 & 0.348 & 0.178 & 0.354 & 0.223 & 0.333 & \\
\hline K & 0.001 & 0.003 & 0.001 & 0.001 & 0.004 & 0.003 & 0.005 & 0.004 & 0.001 & 0.003 & 0.001 & 0.003 & \\
\hline \multirow[t]{2}{*}{ Total } & 4.990 & 4.986 & 4.983 & 4.985 & 4.968 & 4.995 & 5.005 & 4.992 & 4.997 & 4.992 & 4.996 & 4.989 & \\
\hline & \multicolumn{13}{|c|}{ Hole $770 \mathrm{C}$} \\
\hline & Unit D & & & Unit F & & & & & Unit G & & & & \\
\hline Core-Section & $7 R-5$ & & & $11 \mathrm{R}-1$ & & & & & $12 \mathrm{R}-2$ & & & & \\
\hline Interval $(\mathrm{cm})$ & $3-6$ & & & $96-98$ & & & & & $21-33$ & & & & \\
\hline & $\mathrm{Bc}$ & $\mathrm{Br}$ & $\mathrm{g}$ & $\mathrm{Ac}$ & Am & $\mathrm{Ar}$ & mph-c & mph-r & $\mathrm{Ac}$ & Am & $\mathrm{Ar}$ & $\mathrm{Br}$ & $\mathrm{Bc}$ \\
\hline $\mathrm{SiO}_{2}$ & 47.65 & 55.22 & 54.03 & 48.29 & 48.40 & 52.34 & 54.73 & 51.43 & 47.46 & 50.58 & 60.61 & 53.67 & 51.00 \\
\hline $\mathrm{TiO}_{2}^{2}$ & 0.01 & 0.14 & 0.10 & 0.04 & 0.02 & 0.07 & 0.12 & 0.07 & 0.05 & 0.04 & 0.09 & 0.08 & 0.04 \\
\hline $\mathrm{Al}_{2} \mathrm{O}_{3}$ & 33.24 & 27.68 & 27.86 & 32.85 & 32.71 & 29.89 & 27.92 & 29.68 & 33.52 & 31.42 & 24.33 & 28.21 & 30.65 \\
\hline $\mathrm{Fe}_{2} \mathrm{O}_{3}$ & 0.39 & 0.99 & 1.11 & 0.39 & 0.37 & 0.70 & 0.79 & 0.80 & 0.41 & 0.45 & 0.73 & 0.90 & 0.53 \\
\hline $\mathrm{MnO}$ & 0.02 & 0.00 & 0.00 & 0.02 & 0.00 & 0.00 & 0.01 & 0.01 & 0.00 & 0.00 & 0.02 & 0.00 & 0.00 \\
\hline $\mathrm{MgO}$ & 0.23 & 0.27 & 0.45 & 0.28 & 0.22 & 0.19 & 0.10 & 0.11 & 0.24 & 0.28 & 0.08 & 0.23 & 0.27 \\
\hline $\mathrm{CaO}$ & 17.33 & 10.57 & 12.79 & 16.49 & 16.33 & 13.06 & 10.68 & 13.01 & 16.87 & 14.99 & 6.19 & 11.82 & 14.30 \\
\hline $\mathrm{Na}_{2} \mathrm{O}$ & 1.72 & 5.33 & 4.11 & 1.94 & 1.98 & 3.93 & 5.33 & 4.10 & 1.76 & 2.97 & 7.94 & 4.76 & 3.33 \\
\hline $\mathrm{K}_{2} \mathrm{O}$ & 0.01 & 0.11 & 0.06 & 0.00 & 0.01 & 0.07 & 0.13 & 0.07 & 0.00 & 0.01 & 0.21 & 0.07 & 0.02 \\
\hline Total & 100.60 & 100.31 & 100.51 & 100.30 & 100.04 & 100.25 & 99.81 & 99.28 & 100.31 & 100.74 & 100.20 & 99.74 & 100.14 \\
\hline $\mathrm{Si}$ & 2.177 & 2.486 & 2.440 & 2.206 & 2.215 & 2.372 & 2.477 & 2.358 & 2.171 & 2.291 & 2.697 & 2.439 & 2.321 \\
\hline $\mathrm{Ti}$ & 0.000 & 0.005 & 0.003 & 0.001 & 0.001 & 0.002 & 0.004 & 0.002 & 0.002 & 0.001 & 0.003 & 0.003 & 0.001 \\
\hline $\mathrm{Al}$ & 1.790 & 1.469 & 1.483 & 1.769 & 1.764 & 1.596 & 1.490 & 1.604 & 1.808 & 1.677 & 1.276 & 1.511 & 1.644 \\
\hline $\mathrm{Fe}^{+3}$ & 0.013 & 0.034 & 0.038 & 0.013 & 0.013 & 0.024 & 0.027 & 0.028 & 0.014 & 0.015 & 0.024 & 0.031 & 0.018 \\
\hline $\mathrm{Mn}$ & 0.001 & 0.000 & 0.000 & 0.001 & 0.000 & 0.000 & 0.000 & 0.000 & 0.000 & 0.000 & 0.001 & 0.000 & 0.000 \\
\hline $\mathrm{Mg}$ & 0.016 & 0.018 & 0.030 & 0.019 & 0.015 & 0.013 & 0.007 & 0.008 & 0.016 & 0.019 & 0.005 & 0.016 & 0.018 \\
\hline $\mathrm{Ca}$ & 0.848 & 0.510 & 0.619 & 0.807 & 0.801 & 0.634 & 0.518 & 0.639 & 0.827 & 0.727 & 0.295 & 0.576 & 0.697 \\
\hline $\mathrm{Na}$ & 0.152 & 0.465 & 0.360 & 0.172 & 0.176 & 0.345 & 0.468 & 0.365 & 0.156 & 0.261 & 0.685 & 0.420 & 0.294 \\
\hline K & 0.001 & 0.006 & 0.004 & 0.000 & 0.001 & 0.004 & 0.008 & 0.004 & 0.000 & 0.001 & 0.012 & 0.004 & 0.001 \\
\hline Total & 4.998 & 4.993 & 4.977 & 4.988 & 4.984 & 4.991 & 4.998 & 5.008 & 4.994 & 4.992 & 4.998 & 4.999 & 4.995 \\
\hline
\end{tabular}




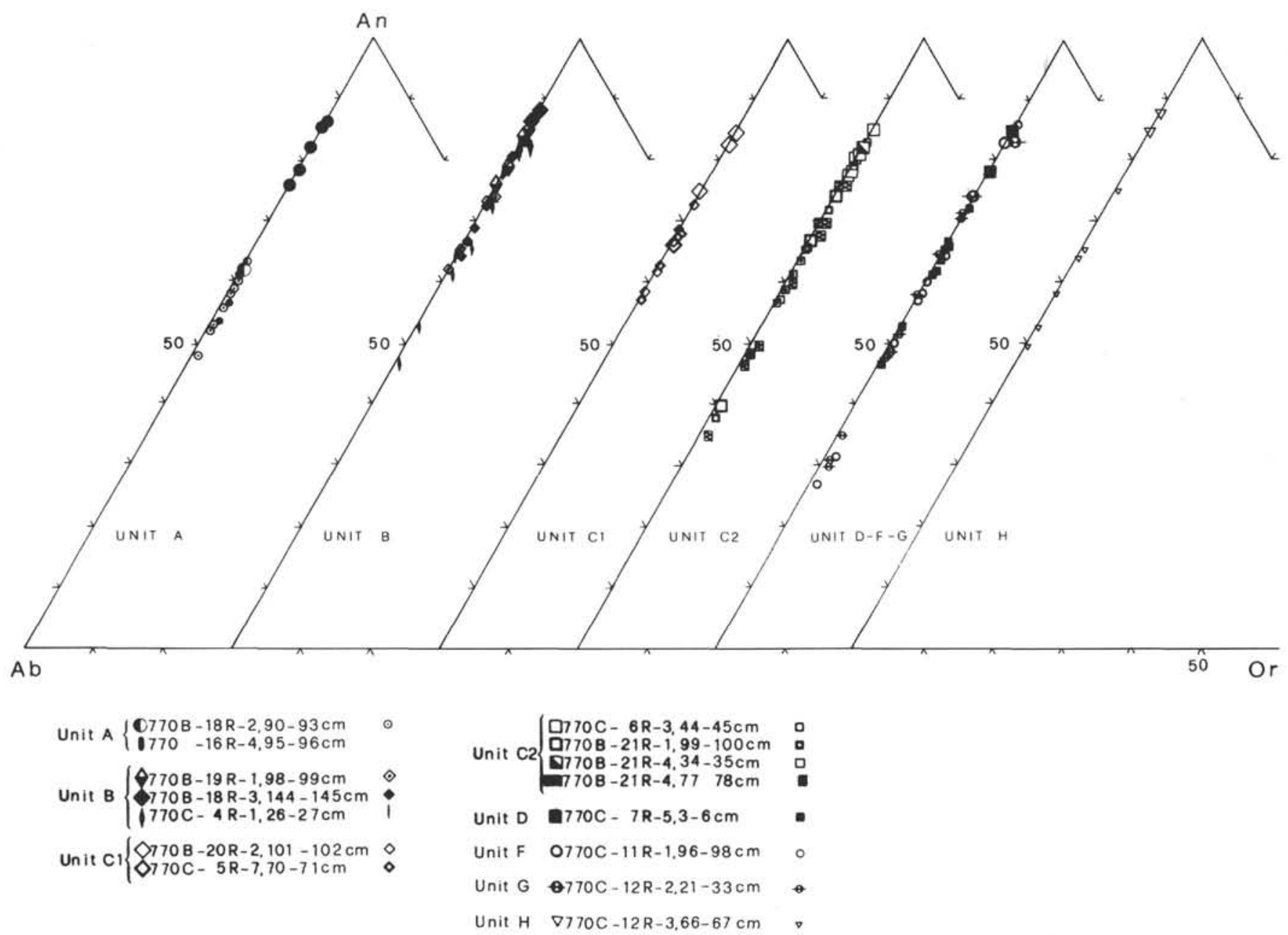

Figure 8. Plagioclase compositions of Celebes basement rocks in the Ab-An-Or diagram (mol \%). Large and small symbols represent core and rim of the same crystal, respectively. 

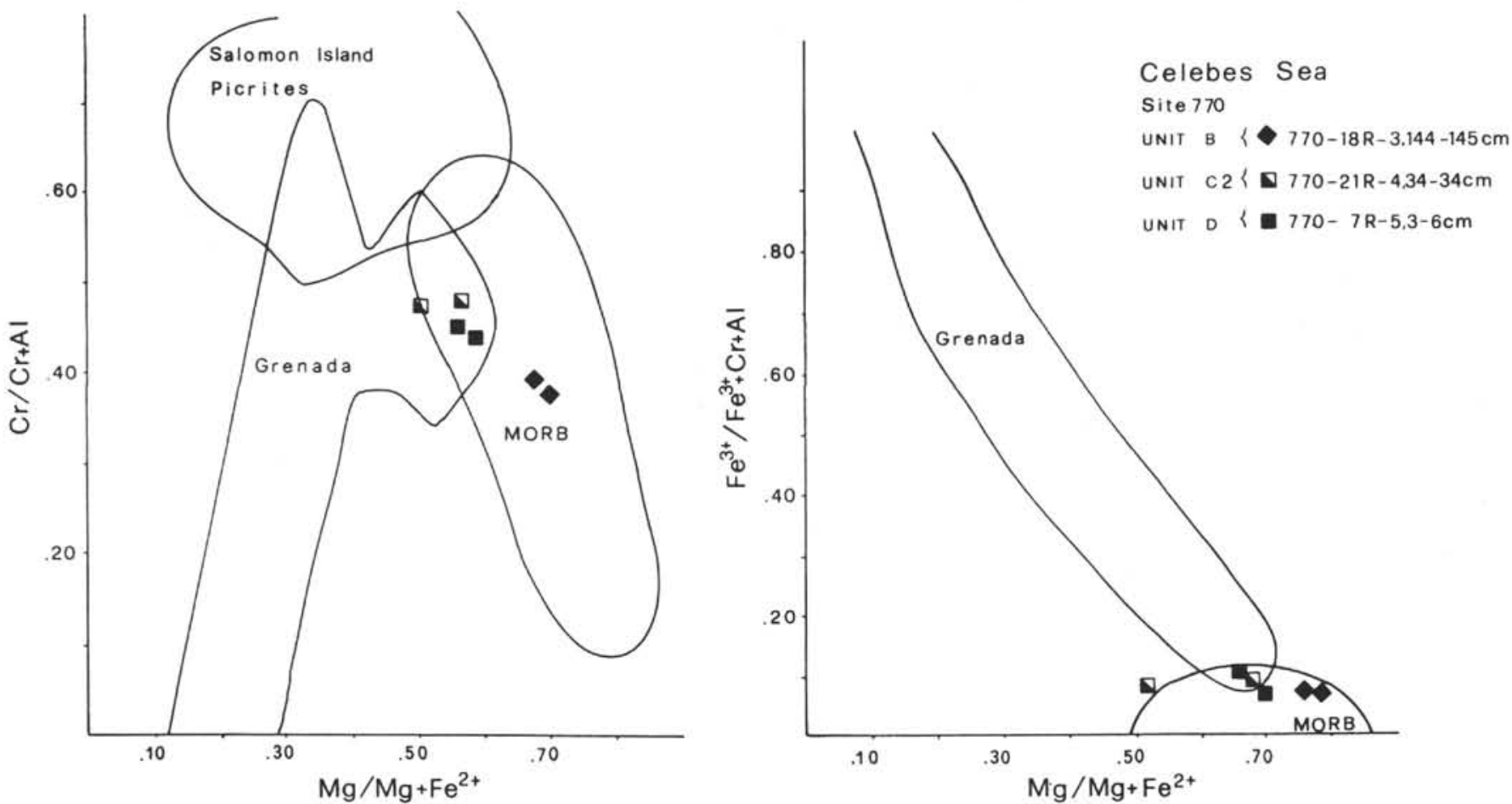

Figure 9. $\mathrm{Cr}$-spinel composition of Celebes basement rocks in the $\mathrm{Cr} /(\mathrm{Cr}+\mathrm{Al})$ vs. $\mathrm{Mg} /\left(\mathrm{Mg}+\mathrm{Fe}^{2+}\right)$ and $\left.\mathrm{Fe}^{3+}+\mathrm{Al}+\mathrm{Cr}\right) \mathrm{vs} . \mathrm{Mg} /\left(\mathrm{Mg}+\mathrm{Fe} e^{2+}\right)$ diagrams. $\mathrm{For}$ comparison, fields for $\mathrm{Cr}$-spinels from Salomon Island picrites, Grenada basanites, and MORB are also reported (after Crawford et al., 1986).

Table 5. Representative major-element analyses (wt \% oxide) of the Celebes basement rocks. Analyses carried out by $\mathrm{XRF} ; \mathrm{mg}=100 \mathrm{Mg} /\left(\mathrm{Mg}+\mathrm{Fe} \mathrm{e}^{2+}\right.$ ) calculated with $\mathrm{Fe}_{2} \mathrm{O}_{3} / \mathrm{FeO}=0.15$. A and $\mathrm{C}$ represent Udine University and-aboard ship analyses, respectively.

Hole $767 \mathrm{C}$ Hole $770 \mathrm{~B}$

Hole $770 \mathrm{C}$

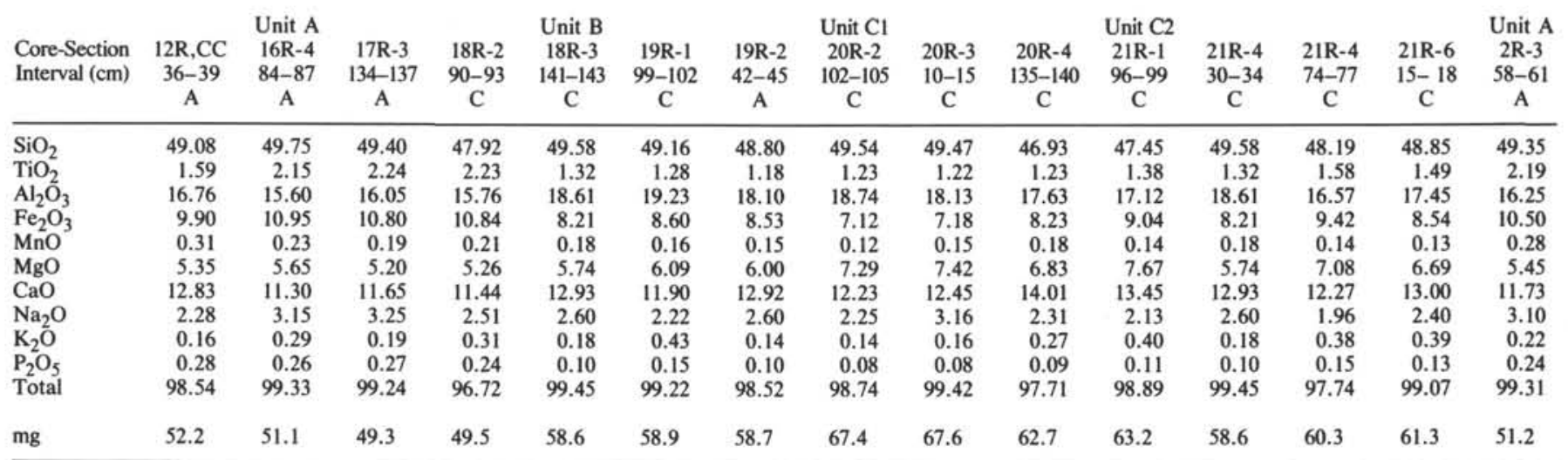

Hole $770 \mathrm{C}$

\begin{tabular}{|c|c|c|c|c|c|c|c|c|c|c|c|c|c|c|c|}
\hline $\begin{array}{l}\text { Core-Section } \\
\text { Interval }(\mathrm{cm})\end{array}$ & $\begin{array}{c}\text { Unit A } \\
2 \mathrm{R}-3 \\
59-62 \\
\mathrm{~A}\end{array}$ & $\begin{array}{c}3 R-2 \\
4-7 \\
A\end{array}$ & $\begin{array}{c}3 \mathrm{R}-3 \\
124-128 \\
\mathrm{~A}\end{array}$ & $\begin{array}{c}3 \mathrm{R}-3 \\
125-128 \\
\mathrm{~A}\end{array}$ & $\begin{array}{c}\text { Unit B } \\
4 \mathrm{R}-1 \\
27-30 \\
\mathrm{C}\end{array}$ & $\begin{array}{c}\text { Unit } \mathrm{Cl} \\
5 \mathrm{R}-2 \\
39-41 \\
\mathrm{C}\end{array}$ & $\begin{array}{c}\text { Unit } C 2 \\
6 \mathrm{R} 3 \\
45-48 \\
\mathrm{C}\end{array}$ & $\begin{array}{c}\text { Unit D } \\
7 \mathrm{R}-5 \\
3-6 \\
\mathrm{C}\end{array}$ & $\begin{array}{c}7 \mathrm{R}-6 \\
44-47 \\
\text { A }\end{array}$ & $\begin{array}{c}\text { Unit E } \\
9 \mathrm{R}-2 \\
42-48 \\
\mathrm{~A}\end{array}$ & $\begin{array}{c}\text { Unit F } \\
10 \mathrm{R}-2 \\
43-47 \\
\mathrm{~A}\end{array}$ & $\begin{array}{c}\text { IIR-I } \\
91-93 \\
\text { C }\end{array}$ & $\begin{array}{c}\text { Unit G } \\
12 R-2 \\
21-33 \\
A\end{array}$ & $\begin{array}{c}12 \mathrm{R}-2 \\
38-41 \\
\mathrm{~A}\end{array}$ & $\begin{array}{c}\text { Unit H } \\
12 \mathrm{R}-3 \\
64-70 \\
\mathrm{~A}\end{array}$ \\
\hline $\mathrm{SiO}_{2}$ & 49.90 & 49.80 & 49.55 & 50.00 & 48.69 & 48.42 & 48.67 & 49.06 & 49.70 & 49.00 & 50.70 & 50.01 & 48.30 & 48.90 & 48.70 \\
\hline $\mathrm{Al}_{2} \mathrm{O}_{3}$ & 16.10 & 16.05 & 16.20 & 16.70 & 17.44 & 17.27 & 16.64 & 17.47 & 16.90 & 15.80 & 15.90 & 16.27 & 15.20 & 15.52 & 17.20 \\
\hline $\mathrm{Fe}_{2} \mathrm{O}_{3}$ & 9.80 & 10.68 & 10.77 & 9.65 & 8.70 & 9.23 & 8.66 & 9.22 & 9.92 & 10.60 & 9.17 & 7.94 & 10.65 & 10.63 & 9.70 \\
\hline $\mathrm{MnO}$ & 0.31 & 0.17 & 0.19 & 0.17 & 0.14 & 0.14 & 0.13 & 0.15 & 0.14 & 0.25 & 0.17 & 0.18 & 0.27 & 0.20 & 0.15 \\
\hline $\mathrm{MgO}$ & 5.37 & 5.30 & 5.55 & 5.25 & 6.32 & 7.35 & 6.53 & 7.41 & 5.70 & 6.52 & 6.10 & 6.55 & 9.05 & 8.67 & 7.30 \\
\hline $\mathrm{K}_{2} \mathrm{O}$ & 0.19 & 0.29 & 0.16 & 0.21 & 0.07 & 0.33 & 0.38 & 0.36 & 0.36 & 0.27 & 0.24 & 0.19 & 0.20 & 0.24 & 0.32 \\
\hline $\mathrm{P}_{2} \mathrm{O}_{5}$ & 0.25 & 0.25 & 0.24 & 0.24 & 0.10 & 0.07 & 0.13 & 0.10 & 0.16 & 0.20 & 0.21 & 0.20 & 0.12 & 0.12 & 0.11 \\
\hline Total & 98.97 & 99.10 & 99.30 & 99.16 & 98.27 & 98.33 & 97.55 & 99.80 & 99.62 & 99.53 & 99.56 & 97.68 & 99.68 & 99.76 & 99.47 \\
\hline $\mathrm{mg}$ & 52.6 & 50.1 & 51.0 & 52.4 & 59.5 & 61.7 & 60.4 & 61.9 & 53.7 & 55.4 & 57.4 & 62.5 & 63.2 & 62.3 & 60.3 \\
\hline
\end{tabular}




\section{G. SERRI ET AL.}

Table 6. Representative trace-element analyses (ppm element), ${ }^{87} \mathrm{Sr} /{ }^{86} \mathrm{Sr}$ and ${ }^{143} \mathrm{Nd} /{ }^{144} \mathrm{Nd}$ ratios of Celebes basement rocks. Columns $\mathrm{A}$ and $\mathrm{C}$ refer to analyses carried out by XRF and ICP (Y and REE, Nancy) methods at Udine University and aboard ship, respectively; columns B refer to analyses carried out by the ICP-MS (St. Johns) method.

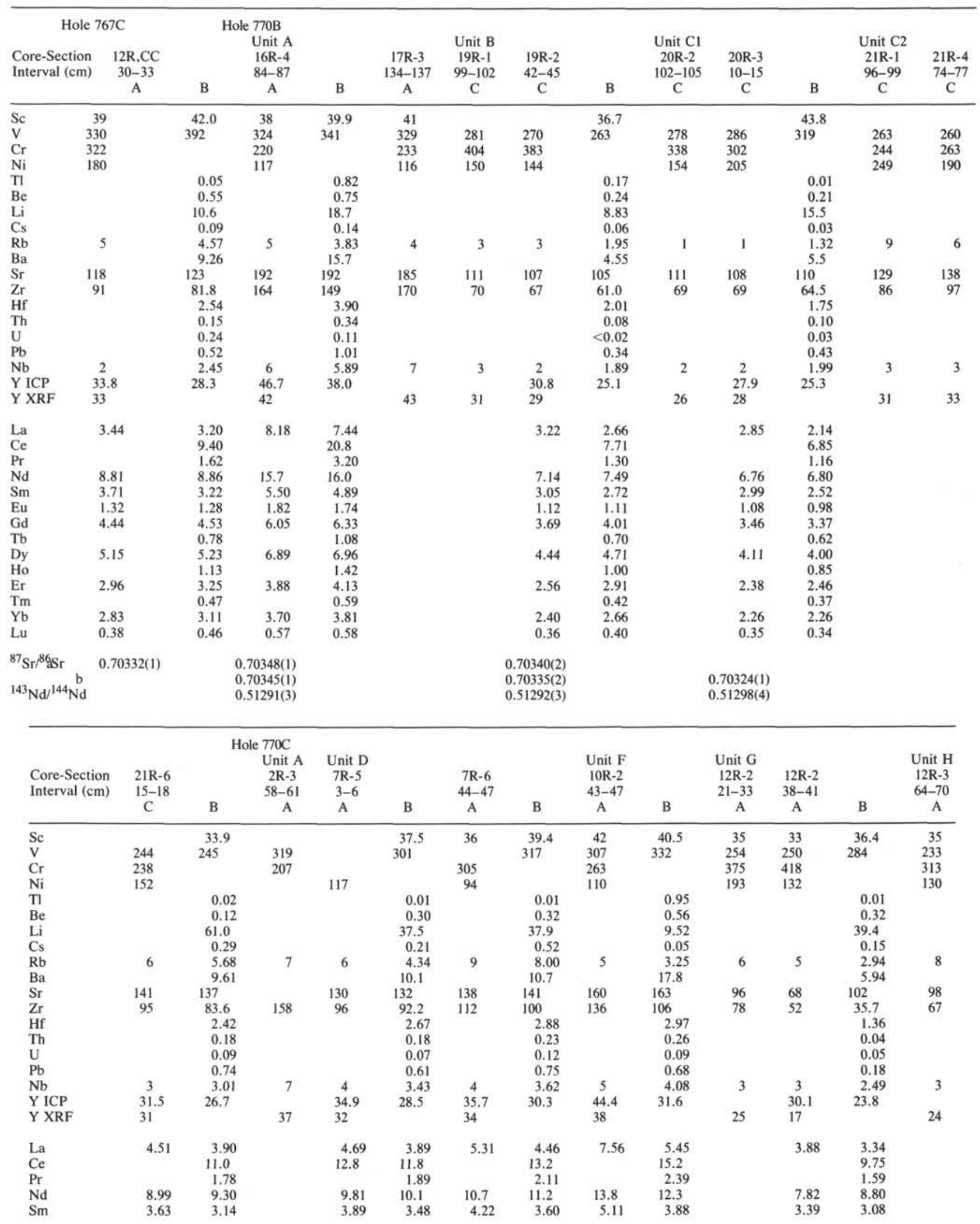


Table 6 (continued).

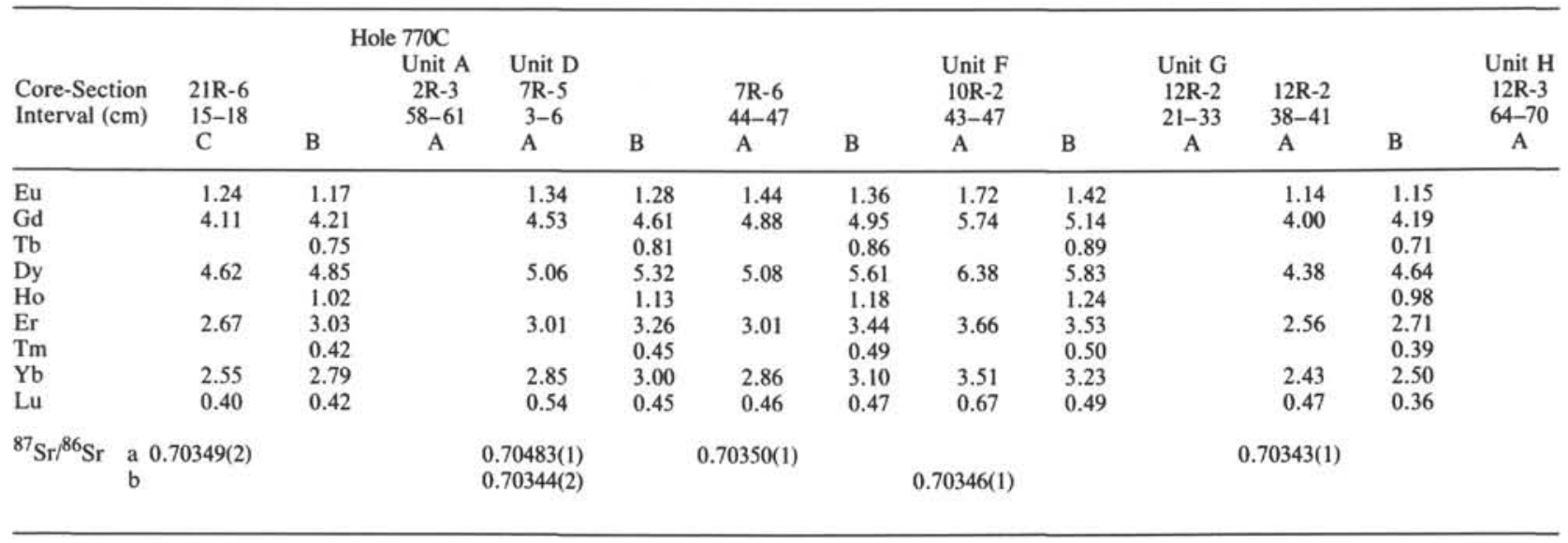
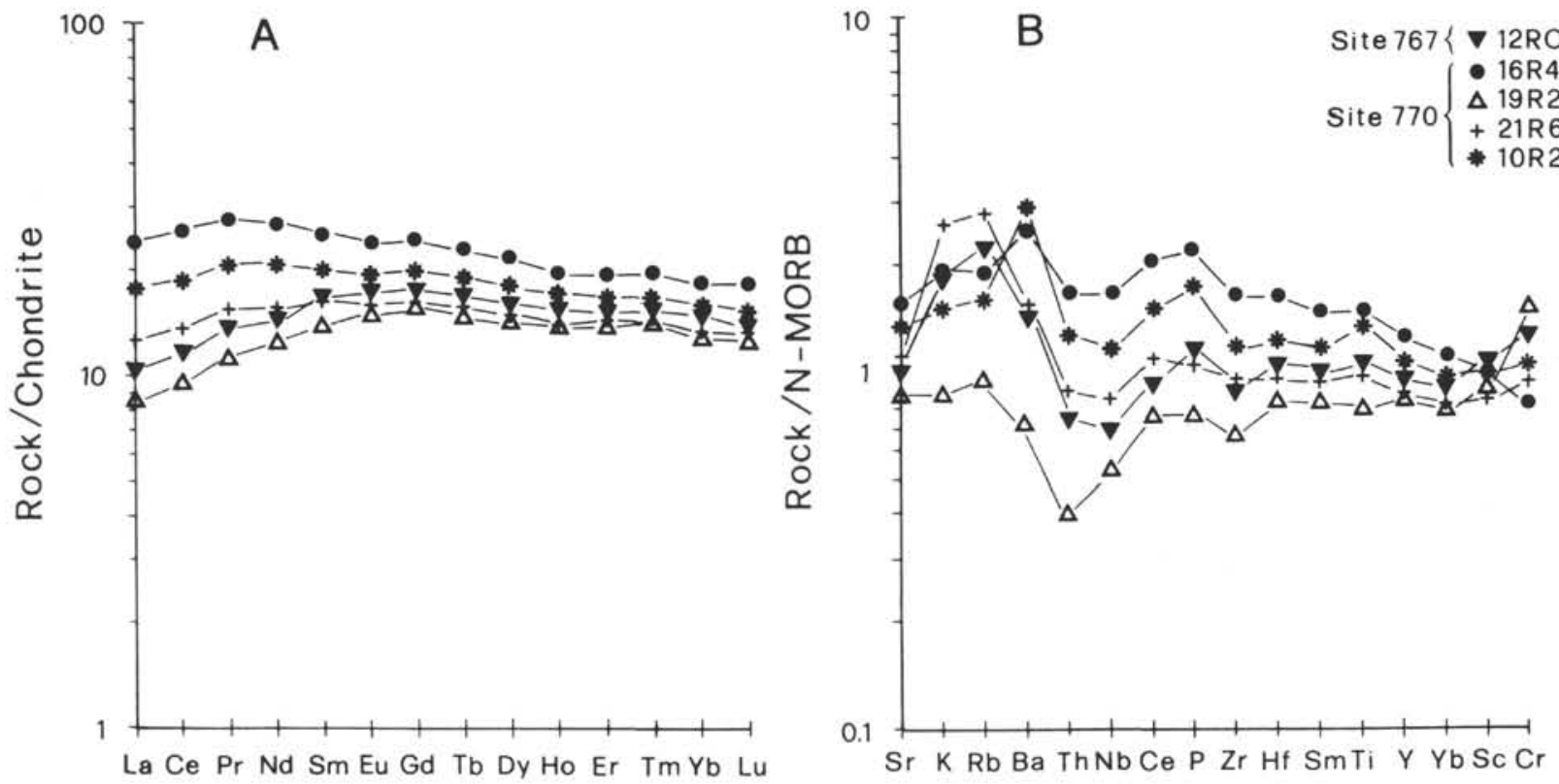

Figure 10. A. Chondrite normalized REE and B. N-MORB normalized trace-element patterns for Celebes basement rocks. Normalizing values according to Taylor and Gorton (1977), and Pearce (1982). For Ba, the normalizing value (6.30 ppm) is taken from Sun and McDonough (1989). 


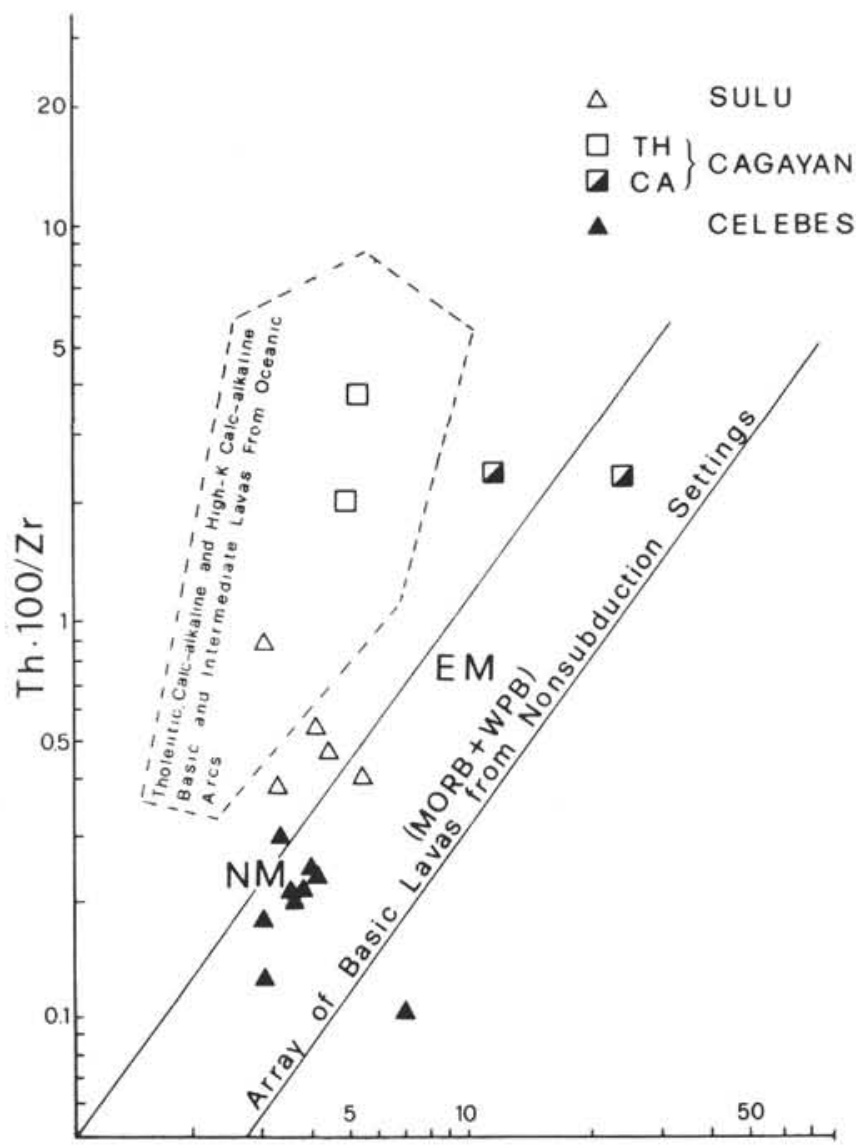

$\mathrm{Nb} \cdot 100 / \mathrm{Zr}$

Figure 11. $\mathrm{Th} / \mathrm{Zr}$ vs. $\mathrm{Nb} / \mathrm{Zr}$ diagram for Celebes basement (filled triangles), Sulu basement rocks (open triangles) and Cagayan Ridge tholeiitic (open squares) and calcalkaline (half-filled squares) basalts. Intraplate/mid-ocean ridge and convergent plate margin basic lavas are clearly discriminated (after Beccaluva et al., 1984). NM and EM, normal and enriched MORB, respectively. 




Figure 12. $\mathrm{Zr} / \mathrm{Y}$ vs. $\mathrm{Zr} / \mathrm{Nb}$ for Celebes Sea basaltic rocks. Field for P-, T-, and N-MORB from Southwest Indian Ridge (SWIR, Le Roex et al., 1983), American Antarctic Ridge (AAR, Le Roex et al., 1985), Atlantic Ridge (ATL, Wood et al., 1979, Le Roex et al., 1981), and N-MORB Atlantic Ridge $22^{\circ}-25^{\circ} \mathrm{N}$ (Bryan et al., 1981) are also reported for comparison. 


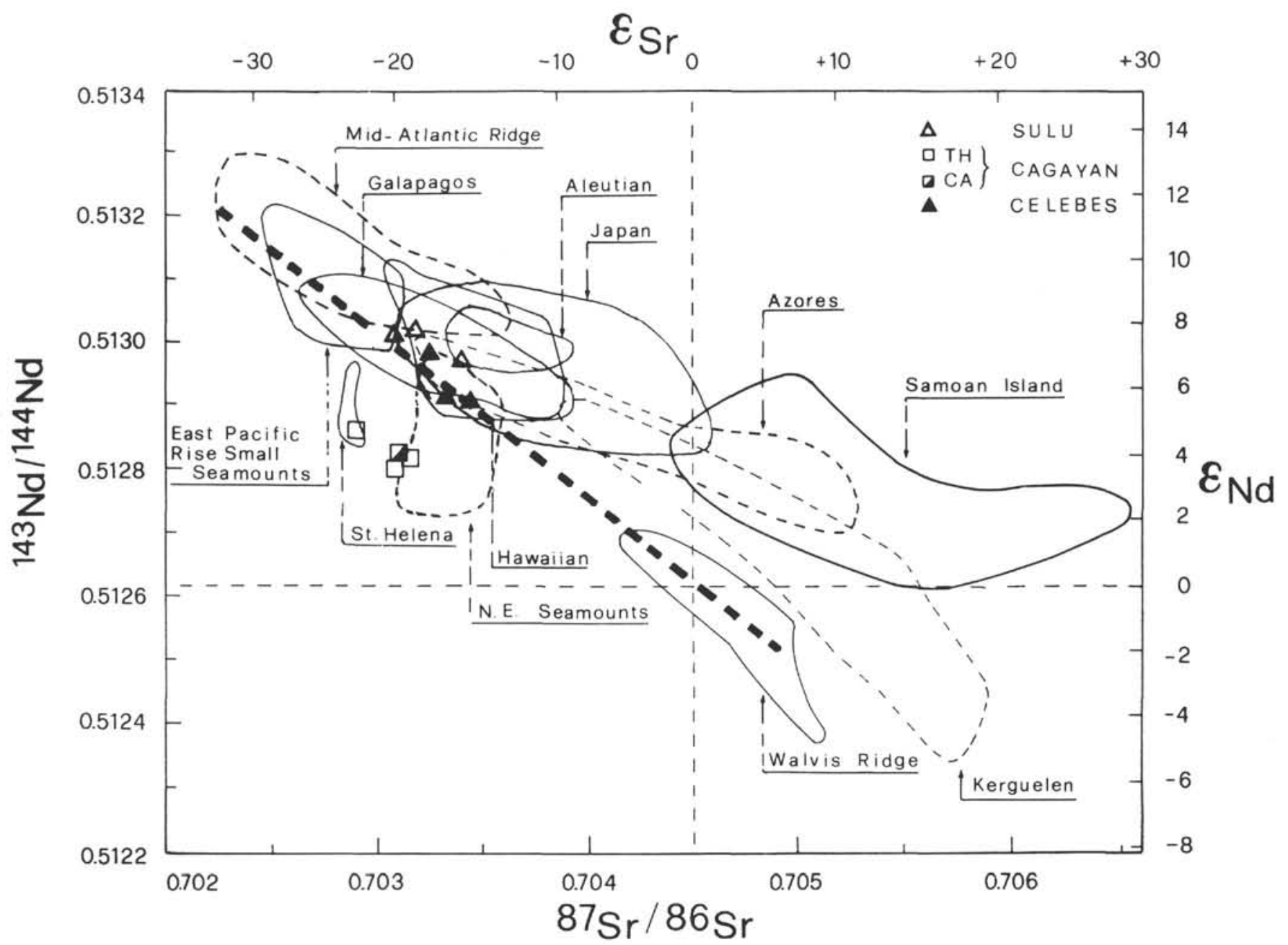

Figure $13 .{ }^{87} \mathrm{Sr} /{ }^{86} \mathrm{Sr}$ vs. ${ }^{143} \mathrm{Nd} /{ }^{144} \mathrm{Nd}$ diagram for basaltic rocks from Celebes Basement, Sulu Basement, and Cagayan Ridge. The mantle array and some compositional fields of MORB, within oceanic plate and arc volcanism are reported (after De Paolo, 1988; Faure, 1986; Hart, 1988). 